\title{
Edible Films and Coatings as Carriers of Living Microorganisms: A New Strategy Towards Biopreservation and Healthier Foods
}

\author{
Ana Guimarães, Luís Abrunhosa iD , Lorenzo M. Pastrana, and Miguel A. Cerqueira iD
}

\begin{abstract}
Edible films and coatings have been extensively studied in recent years due to their unique properties and advantages over more traditional conservation techniques. Edible films and coatings improve shelf life and food quality, by providing a protective barrier against physical and mechanical damage, and by creating a controlled atmosphere and acting as a semipermeable barrier for gases, vapor, and water. Edible films and coatings are produced using naturally derived materials, such as polysaccharides, proteins, and lipids, or a mixture of these materials. These films and coatings also offer the possibility of incorporating different functional ingredients such as nutraceuticals, antioxidants, antimicrobials, flavoring, and coloring agents. Films and coatings are also able to incorporate living microorganisms. In the last decade, several works reported the incorporation of bacteria to confer probiotic or antimicrobial properties to these films and coatings. The incorporation of probiotic bacteria in films and coatings allows them to reach the consumers' gut in adequate amounts to confer health benefits to the host, thus creating an added value to the food product. Also, other microorganisms, either bacteria or yeast, can be incorporated into edible films in a biocontrol approach to extend the shelf life of food products. The incorporation of yeasts in films and coatings has been suggested primarily for the control of the postharvest disease. This work provides a comprehensive review of the use of edible films and coatings for the incorporation of living microorganisms, aiming at the biopreservation and probiotic ability of food products.
\end{abstract}

Keywords: antimicrobial, bacteria, bioactive, packaging, yeast

\section{Introduction}

Edible films and coatings can be useful in extending product shelf life while maintaining their nutritional and sensory qualities. Even though edible packaging is not yet regarded as a substitute for more traditional forms of packaging, it presents numerous advantages. With edible films and coatings, it is possible to improve functionalities of food products. For example, it is possible to add nutrients that were absent in the original product, incorporate antioxidants, and antibrowning agents to delay degradation of nutrients and flavors, and add antimicrobial agents that can delay proliferation of foodborne pathogens and spoilage microorganisms (Rojas-Graü, Soliva-Fortuny, \& Martín-Belloso, 2009). The possibility of using edible films and coatings to incorporate living microorganisms creates new opportunities and also new challenges in the food industry.

Edible coatings with the incorporation of yeasts have been reported over 20 years in the control of postharvest disease in fruits.

CRF3-2017-0220 Submitted 11/7/2017, Accepted 2/16/2018. Authors Guimarães and Abrunhosa are with Centre of Biological Engineering, Univ. of Minho, Campus de Gualtar, 4710-057 Braga, Portugal. Authors Pastrana and Cerqueira are with Intl. Iberian Nanotechnology Laboratory, Av. Mestre José Veiga s/n, 4715-330 Braga Portugal. Direct inquiries to author Abrunhosa (E-mail: luisjap@deb.uminho.pt).
These early works used Candida spp. incorporated in cellulose or shellac coatings to prevent the proliferation of naturally grown pathogens. Yeast cells remained viable within the coatings and were able to reduce decay (McGuire \& Baldwin, 1994; McGuire \& Dimitroglou, 1999; McGuire \& Hagenmaier, 1996; Potjewijd, Nisperos, Burns, Parish, \& Baldwin, 1995). In the last decade, new research focused on other film-forming materials for the incorporation of yeasts (for example, alginate and chitosan) appear with the objective of improving microorganism survival but also barrier and mechanical properties without affecting the reduction of decay in fruits and vegetables (Aloui, Licciardello, Khwaldia, Hamdi, \& Restuccia, 2015; Fan et al., 2009; Sharma, Verma, \& Awasthi, 2006; Yinzhe \& Shaoying, 2013). In addition, bacterial microorganisms started being incorporated into films and coatings, either to confer a probiotic ability to the food product or to act as an antimicrobial agent. In general, it is reported that the incorporation of probiotic bacteria in edible films and coatings increase their survival rate (Altamirano-Fortoul, Moreno-Terrazas, Quezada-Gallo, \& Rosell, 2012; Kanmani \& Lim, 2013; Soukoulis et al., 2014b; Soukoulis, Behboudi-Jobbehdar, Macnaughtan, Parmenter, \& Fisk, 2017; Tapia et al., 2007), and that incorporation of bacterial strains with antimicrobial properties results in an increase of shelf life for coated food products (Concha-Meyer, Schöbitz, Brito, \& Fuentes, 2011; Gialamas, Zinoviadou, Biliaderis, \& Koutsoumanis, 2010; Sánchez-González, Quintero Saavedra, \& Chiralt, 
2013; Sánchez-González, Quintero Saavedra, \& Chiralt, 2014). However, mechanical and barrier properties of these films and coatings are, sometimes, affected by the incorporation of these microorganisms (Kanmani \& Lim, 2013; Sánchez-González et al., 2013, 2014).

The main objective of this review is to give an overview of the current state of the art regarding the use of edible films and coatings as carriers for viable microorganisms.

With that objective the review is divided into different sections, namely: Introduction; Edible films and coatings; Probiotic activity of microorganisms; Antimicrobial activity of microorganisms; Antimicrobial activity of bacteria; Antimicrobial activity of yeasts; Use of edible films and coatings as carriers of living microorganisms; Bacteria; Yeast; and Conclusion and future trends.

This information will be useful to identify the new opportunities and current problems in the incorporation of microorganisms in edible films and coatings. In addition, it can be an aid to indicate future trends and new functionalities of edible films and coatings.

\section{Edible Films and Coatings}

In the last decades, there has been a growing interest in edible films and coatings. This interest has been driven by the consumer demand for high quality and healthy food, by environmental concerns and by the need of new preservation techniques able to answer to new products requirements. These new preservation techniques, through edible films and coatings, can improve food quality and safety, while providing a semipermeable barrier to water vapor and gases between the food and the surrounding atmosphere (Lin \& Zhao, 2007). They also meet environmental concerns since they are usually produced with by-products from agricultural and marine sources, replacing food packaging made of nonrenewable sources and consequently reducing waste products (Tharanathan, 2003).

Although the terms films and coatings are sometimes used as synonyms, they represent different concepts. Films are usually defined as a thin layer of material that can be used as a cover or wrap, whereas coatings are directly formed on the surface of the product they are intended to protect (Gennadios, 2002). Because of the fact of being consumed together with the food product, edible films and coatings are simultaneously a packaging and a food component, thus they must meet some specifications. For example, they should have good barrier and mechanical properties, excellent physic-chemical and microbiologic stability, be organoleptically and functionally compatible with food, be nontoxic and safe for health, and have a low production cost (Debeaufort, Quezada-Gallo, \& Voilley, 1998). Moreover, they should fit on the legislation requisites of the country where they are sold (Cerqueira, Teixeira, \& Vicente, 2016).

The primary materials used for the production of edible films and coatings are polysaccharides, proteins, and lipids or a combination of these materials. Individually, each material can form films or coatings with specific properties, but the use of combinations of materials and the addition of plasticisers and surfactants are usually one of the approaches to enhance their final properties (that is, flexibility, barrier and optical properties) (Campos, Gerschenson, \& Flores, 2010). The selection of the materials is based on their physical and chemical characteristics that influence the final properties of films and coatings. It is desirable to have a film with good water vapor barrier properties to retard surface dehydration, especially in fresh products; but also with good gas control, especially for oxygen, to reduce oxidation and rancidity. Hydrophobic substances or lipids are practical barriers against moisture transfer whereas most of polysaccharides and proteins show poorer barrier properties against moisture transfer. Polysaccharides and proteins based films also have low permeability to gases and better mechanical properties than lipid-based films. The appearance of the films is also dependent on the film forming material (Debeaufort et al., 1998). The optimization of film or coating composition is crucial to their successful application because they must be formulated according to their purpose and the properties of the food product in which they are going to be applied.

In recent years, the development of active edible films and coatings has been proposed for the increase of shelf life and maintenance or even improvement in the quality of the food products. This principle is based either on the properties of the films and coating material or the introduction of active compounds (Dainelli, Gontard, Spyropoulos, Zondervan-van den Beuken, \& Tobback, 2008) that will interact with the food or the food environment. Active compounds possess several functional properties that can improve quality and extend shelf life of food products (for example, antioxidants, anti-browning agents), enhance their sensory properties (for example, flavor, color, and texture), delay microbial decay (for example, antimicrobials) and bring health benefits to the consumer (for example, nutraceuticals such as vitamins, minerals, prebiotics, and probiotics). Although the incorporation of bioactive components in food products can bring many advantages, these compounds can, in some cases, alter the flavor, be susceptible to fast degradation, interact negatively with other elements of the food matrix, and have limited solubility (QuirósSauceda, Ayala-Zavala, Olivas, \& González-Aguilar, 2014). In this context, the use of edible films and coatings as a matrix to encapsulate bioactive compounds is a strategy that can protect against environmental conditions that cause destruction or inactivation of these substances. Integration in an edible films and coatings can, in addition, improve compound solubility and provide control release of the substances while maintaining the food product sensory and nutritional characteristics (Falguera, Quintero, Jiménez, Muñoz, \& Ibarz, 2011; Quirós-Sauceda et al., 2014).

Incorporation of living microorganisms in edible films and coatings brings additional challenges; they must remain viable in sufficient concentrations to exert probiotic effects or antimicrobial activity, although not altering barrier and mechanical properties of the film or coating, and not changing sensory properties of the food product. Addition of living microorganisms in edible films and coatings has been recently reported by several authors and is reviewed in a posterior section of this review.

\section{Probiotic Activity of Microorganisms}

Living microorganisms have been used in several food products, mainly because of their probiotic activity. Probiotics are live microorganisms, which at a given concentration can confer health benefits to the host (Sanders, 2008). Probiotics help to support the growth of preferred and existing microorganisms, reduce potentially harmful bacteria, and reinforce the natural defense mechanisms of the body (Gismondo, Drago, \& Lombardi, 1999; Holzapfel, Haberer, Snel, Schillinger, \& Veld, 1998). Also, probiotics have been described to cause cell-mediated immune responses, including activation of the reticuloendothelial system, augmentation of cytokine pathways and stimulation of proinflammatory pathways such as tumor necrosis factors and interleukin regulation, without being a target of the host immune system (Anal \& Singh, 2007). Saarela, Mogensen, Fondén, Matto, and MattilaSandholm (2000) have reviewed clinical effects of some probiotic strains in humans. In resume, probiotics are said to reduce lactose 
intolerance, lower blood cholesterol, increase immune response, prevent infections by pathogenic organisms, reduce diarrhea, and prevent cancer.

Lactic acid bacteria (LAB) represent the major group of probiotic bacteria in the food industry. LAB are indeed good candidates to be used as probiotics since several LAB strains are native to the human oral cavity and intestinal tract and have a positive influence, preventing the growth of harmful microbiota, and modulating mucosal immunity in these environments (Bosch et al., 2012; Holzapfel \& Schillinger, 2002; Ohland \& MacNaughton, 2010). LAB are generally recognized as safe (GRAS) organisms and have been used as starter cultures in the production of fermented dairy products (Leroy \& De Vuyst, 2004). The most commonly used LAB for the probiotic function has been lactobacilli such as Lactobacillus acidophilus and Lactobacillus rhamnosus. Other bacteria used as probiotic includes Bifidobacteria, generally called Bifidus (Saarela et al., 2000), and also species belonging to the genera Lactococcus and Enterococcus (Douglas \& Sanders, 2008). Some yeasts also have probiotic properties. The first yeast to be reported as a probiotic for human consumption was Saccharomyces cerevisiae var. boulardii (Surawicz et al., 1989). Since then, several yeast species such as Debaryomyces hansenii, Torulaspora delbrueckii, Kluyveromyces lactis, Yarrowia lipolytica, S. cerevisiae, Kluyveromyces marxianus, and Kluyveromyces lodderae demonstrated potential probiotic ability (Ceugniez et al., 2017; Kumura, Tanoue, Tsukahara, Tanaka, \& Shimazaki, 2004; Psani \& Kotzekidou, 2006; van der Aa Kühle, Skovgaard, \& Jespersen, 2005), but only S. boulardii is still considered an effective probiotic (Sazawal et al., 2006). Yeasts may offer some advantages as probiotics when compared with bacteria. They are insensitive to antibiotics, thus being especially relevant in the treatment of diarrhea and intestinal infections caused by the administration of antibiotics, and can produce compounds of interest such as vitamins (Czerucka, Piche, \& Rampal, 2007; Silva et al., 2011; Surawicz et al., 1989). Regarding S. boulardii, many clinical trials have proven its efficiency and are reviewed elsewhere (Czerucka et al., 2007). Effects of probiotics are strain specific, so genus, species, and strain of probiotic need to be specified when proclaiming health benefits (Burgain, Gaiani, Linder, \& Scher, 2011).

About 500 probiotic food products have been introduced in the market during the last years (Tripathi \& Giri, 2014). Products available commercially are, for example, traditional yoghurt and other fermented dairy products, such as cheese, ice cream, and fermented baby formula (Cruz, Antunes, Sousa, Faria, \& Saad, 2009; Gueimonde et al., 2004; Ibrahim et al., 2010; LourensHattingh \& Viljoen, 2001; Young, 1998).

Besides exerting a beneficial health effect, the criteria for a microbial strain to be used as a probiotic include the ability of: remaining viable at high cell count throughout the manufacture and storage of the product; withstand transit in the gastrointestinal tract (survive to low $\mathrm{pH}$ and bile); adhere to intestinal epithelium and colonize the gut; be tolerated by the immune system; and produce antimicrobial substances against pathogens (Dunne et al., 2001; Ljungh \& Wadstrom, 2005; Parvez, Malik, Kang, \& Kim, 2006; Saarela et al., 2000). In addition, their incorporation in food should not alter the texture or the flavor of the product.

Despite all the potential benefits of applying probiotics in food commodities, there are still limitations for their use. The concentration of probiotic cells may suffer huge variations from the initial point of incorporation in the food product until they reach the gastrointestinal tract, and the application of probiotics in nondairy products is still technically a challenge. It is usually assumed that to exert a health-promoting effect for the consumer probiotic bacteria concentration must be above $10^{6} \mathrm{CFU} / \mathrm{g}$ of product per day (Burgain et al., 2011). Even so, with the increasing demand for healthier food products, innovative strategies to incorporate probiotics into the most diverse products are being developed. Infant formula (Braegger et al., 2011), fruit and vegetable drinks (Luckow \& Delahunty, 2004; Sheehan, Ross, \& Fitzgerald, 2007; Yoon, Woodams, \& Hang, 2004), cereals (Angelov, Gotcheva, Kuncheva, \& Hristozova, 2006; Charalampopoulos, Pandiella, \& Webb, 2003), soy products (Farnworth et al., 2007; Wang, Yu, \& Chou, 2006), and diverse supplements have been used as carriers for probiotic cultures (Rivera-Espinoza \& Gallardo-Navarro, 2010; Saarela et al., 2000).

The success of probiotic incorporation in food matrices is dependent on several factors, for example, $\mathrm{pH}$, temperature, competition with other microorganisms and inhibitors; and also, on the chemical composition of the food product in which they are added, for example, water activity, carbon, nitrogen, mineral, and oxygen (Rivera-Espinoza \& Gallardo-Navarro, 2010). In addition, it is necessary to consider that probiotic cultures usually do not multiply within most food products, which impairs probiotic stability, and that some products are usually stored at room temperature, which can create an additional challenge to probiotic cultures (Mattila-Sandholm et al., 2002). The limitations of the use of probiotics in food commodities, namely usage in non-dairy products, and viability and stability of probiotics, can be overcome by providing probiotic cells with a physical barrier to withstand adverse environmental conditions (that is, capsules and/or films) (Ramos, Cerqueira, Teixeira, \& Vicente, 2017).

\section{Antimicrobial Activity of Microorganisms Antimicrobial activity of bacteria}

Besides probiotic function, LAB are capable of inhibiting several pathogenic microorganisms in food, thus displaying an essential role in food preservation and safety (De Vuyst \& Leroy, 2007). Compounds produced by LAB are "natural" and thus regarded as a biological method to ensure the safety of food products, allowing the reduction of chemical preservatives or other antimicrobial treatments.

The most readily recognized antimicrobial activity of LAB is the production of lactic and acetic acid. These acids act by reducing the environmental $\mathrm{pH}$ and interrupting the transport of substrates (Campos et al., 2010). LAB are also able to produce other antimicrobial molecules such as ethanol, fatty acids, hydrogen peroxide, and small peptides. In addition, many LAB strains produce bacteriocins such as nisin, reuterin, reutericyclin, pediocin, lacticin, and entorocin or bacteriocin-like inhibitory substances (Leroy \& De Vuyst, 2004; Schnürer \& Magnusson, 2005). The exact mechanism of antimicrobial action is complex and often involves synergistic interaction between compounds (Gálvez, Abriouel, López, \& Omar, 2007). These inhibitory compounds are metabolites of fermentation. However, antimicrobial activity may also occur due to cell lysis, as well as competition for nutrients, exclusion of the targeted pathogen from entry sites in the food matrix, and alterations of microorganism membrane (Pawlowska, Zannini, Coffey, \& Arendt, 2012).

Many studies focus on the ability of LAB to produce organic acids as an antimicrobial strategy. Organic acids are end products of carbohydrate fermentation by LAB and are considered safe agents for the preservation of food. The production of these substances lowers the $\mathrm{pH}$, causing acidification of cell cytoplasm and allowing the undissociated form of the acid to diffuse across the 
target organism membrane. The undissociated acid acts by collapsing the proton gradient or by altering membrane permeability This creates unfavorable conditions for the growth of potentially pathogenic microorganisms in both food products and the human intestinal microflora (Ammor, Tauveron, Dufour, \& Chevallier, 2006). Organic acids that have been used as antimicrobial agents include acetic, benzoic, citric, lactic, malic, propionic, sorbic, and tartaric acid, among others, with acetic acid being described as the most effective in fungal inhibition (Dalié, Deschamps, \& RichardForget, 2010; Peláez et al., 2012). Also, phenyllactic acid (PLA) has been identified as an antimicrobial agent, with PLA effect being demonstrated against several fungi isolated from food products (Gerez, Carbajo, Rollan, Torres Leal, \& Font de Valdez, 2010; Lavermicocca et al., 2000; Ström, Sjögren, Broberg, \& Schnürer, 2002). PLA has, also, been found to be involved in the formation of flavors (Valerio, Lavermicocca, Pascale, \& Visconti, 2004). Organic acids produced by $\mathrm{LAB}$ has been reported to inhibit a vast range of pathogenic microorganisms, such as Helicobacter pylori, Escherichia coli, Pseudomonas aeruginosa, Salmonella enterica, and Listeria monocytogenes (Alakomi et al., 2000; Lin et al., 2009).

Other authors have reported that some bacterial strains can produce antifungal compounds that loose activity in the presence of proteolytic enzymes (Atanassova et al., 2003; Magnusson \& Schnurer, 2001; Voulgari et al., 2010); thus, concluding that certain strains of bacteria can produce antimicrobial peptides. Despite many works reporting the existence of antimicrobial peptides, there is still insufficient evidence of the role of these compounds in the inhibition of microbial growth.

Gourama and Bullerman (1997) reported that antifungal activity of a Lactobacillus casei subsp. pseudoplantarum strain was sensitive to trypsin and $\alpha$-chymotrypsin, which suggests the presence of antifungal protein compounds in the medium. The authors concluded that the molecule involved in the antifungal effect was a peptide of low molecular mass. Also, Magnusson and Schnurer (2001) reported that the compounds involved in the antifungal activity of Lactobacillus coryniformis subsp. coryniformis were heat stable, small $(3 \mathrm{kDa})$ and sensitive to proteolytic enzymes, thus suggesting that antifungal activity was related to proteinaceous compounds. Atanassova et al. (2003) characterized a proteinaceous compound produced by Lactobacillus paracasei subsp. paracasei, with broad antimicrobial activity. This protein was a hydrophobic compound of approximately $43 \mathrm{kDa}$. Also, Voulgari et al. (2010) found that proteinaceous compounds were responsible for the antifungal activity of LAB strains isolated from dairy products. Cyclic dipeptides have also been identified as antifungals in LAB. These include cyclo (Phe-Pro), cyclo (Phe-OH-Pro), and cyclo (Gly-L-Leu) (Dal Bello et al., 2007; Magnusson, Ström, Roos, Sjögren, \& Schnürer, 2003; Niku-Paavola, Laitila, Mattila-Sandholm, \& Haikara, 1999; Ström et al., 2002).

LAB can additionally produce another category of proteinaceous compounds, the bacteriocins. These substances have received significant attention as a novel approach to control food pathogens. Bacteriocins are small peptides or proteins synthesized in the cell ribosomes, that act against closely related bacteria, without affecting the producer cells (Nes \& Holo, 2000). Bacteriocins are regarded as safe for human consumption, given that they can be degraded in the gastrointestinal tract. These substances are particularly active against Gram-positive bacteria, such as foodborne pathogens L. monocytogenes and Staphylococcus aureus, Clostridium spp. (Hernández, Cardell, \& Zárate, 2005; Messi, Bondi, Sabia, Battini, \& Manicardi, 2001). To affect Gram-negative pathogens, such as E. coli and Salmonella spp., target microorganisms outer membrane must be compromised by, for example, osmotic shock, low $\mathrm{pH}$ treatment, detergent or chelating agent, pulsed electric field or high-pressure treatments (De Vuyst \& Leroy, 2007). Bacteriocins can inhibit pathogens at low concentrations and, usually, do not affect the food product sensorial characteristics (Rodgers, 2001).

When inoculating $\mathrm{LAB}$ directly onto the food product, under conditions that favor production of bacteriocins, their production is constant, thus overcoming the problem of decomposition when used as an additive (Rodgers, 2001). Moreover, incorporating bacteriocins producing strains lowers the cost of biopreservation since there is no need for recovery and purification steps (Gálvez et al., 2007). However, bacteriocins are less heat sensitive than live cultures, are easy to handle and store and can be added to food without significant modifications in the preparation methods (Rodgers, 2008). The efficiency of bacteriocins in the food product will be dependent on the interaction with the food components, and on the possibility of distribution and inactivation in the food matrix. Also, the satisfactory effect of bacteriocins depends on the microbial load of the target microorganism and of its sensitivity to the bacteriocin (Gálvez et al., 2007).

Reuterin has also been described as an active antimicrobial produced by certain LAB strains. It has been discovered initially in Lactobacillus reuteri and has broad antimicrobial spectra. It can suppress ribonuclease activity, the enzyme which catalyzes the 1st step in DNA synthesis (Axelsson, Chung, Dobrogosz, \& Lindgren, 1989). This compound is produced from glycerol by starving cells in anaerobic conditions. Primary reuterin producers are L. reuteri, Lactobacillus brevis, Lactobacillus buchneri, Lactobacillus collinoides, and L. coryniformis (Claisse \& Lonvaud-Funel, 2000; Magnusson, 2003) and the addition of glycerol to reuterin producing cultures has been proven to increase its inhibitory effect against several fungi and yeast (Magnusson, 2003; Magnusson \& Schnurer, 2001). Reuterin is active against Gram-positive and Gram-negative bacteria, fungi, and yeasts. Its inhibitory effect has been described for Salmonella spp., E. coli, Candida albicans, and Aspergillus and Fusarium spp., among other pathogens (Chung, Axelsson, Lindgren, \& Dobrogosz, 1989; Spinler et al., 2008).

Also, fatty acids produced by LAB can have antimicrobial properties and can additionally improve sensory properties of fermented food (Leroy \& De Vuyst, 2004). For straight-chained fatty acids, antimicrobial activity increases with chain length, with caprylic $\left(\mathrm{C}_{8}\right)$ acid and longer fatty acids being the most effective. Because of low solubility in water, chains of fatty acids with more than 10 carbons are not as efficient as antimicrobial compounds (Woolford, 1975). However, Sjogren, Magnusson, Broberg, Schnurer, and Kenne (2003) have described the antifungal activity of a 12 carbon hydroxylated fatty acid produced by a strain of Lactobacillus plantarum, and Kabara \& Marshall (1993) reported that fatty acids with 12 to 16 carbons are the most effective. Hydroxylated fatty acids have potent antifungal activity against a large number of microorganisms, with minimum inhibitory concentration ranging from 10 and $100 \mu \mathrm{g} / \mathrm{mL}$ (Sjogren et al., 2003). Fatty acids production kinetics follows bacterial growth, suggesting that these compounds do not result from cell lysis (Sjogren et al., 2003).

Most LAB are also able to produce hydrogen peroxide $\left(\mathrm{H}_{2} \mathrm{O}_{2}\right)$ in the presence of oxygen, by oxidizing lactate (Kandler, 1983). Because $\mathrm{LAB}$ do not produce catalase, hydrogen peroxide accumulates in the environment and oxidizes the lipid membrane and cellular proteins of target organisms (Condon, 1987). In some foods, the effect of hydrogen peroxide is potentiated by lactoperoxidase 
and thiocyanate, both present in milk and saliva. Lactoperoxidase catalyzes the oxidation of thiocyanate using hydrogen peroxide as a substrate, which results in the formation of highly reactive oxidizing agents (Seifu, Buys, \& Donkin, 2005). This reaction ultimately leads to the death of the cells (Kussendrager \& van Hooijdonk, 2000). Already in 1970, Price and Lee (1970) demonstrated that $\mathrm{H}_{2} \mathrm{O}_{2}$ produced by Lactobacillus species was able to inhibit Pseudomonas spp. More recently, Ponts, Pinson-Gadais, Verdal-Bonnin, Barreau, \& Richard-Forget (2006) found that hydrogen peroxide may affect spore germination in F. graminearum. Edema and Sanni (2008) hypothesized that hydrogen peroxide had an essential role in the antimicrobial activity of several lactobacilli against Salmonella typhi, E. coli, S. aureus, and Aspergillus flavus.

The amount and type of antimicrobial compounds produced by $\mathrm{LAB}$ during fermentation process will depend on LAB strains, culture medium composition and growth conditions (Ammor et al., 2006). The efficiency of antimicrobial compounds produced by $\mathrm{LAB}$ can be compromised by several factors when added directly to the food product. Diffusion of antimicrobial agents to the bulk of the food, temperature, processing, alteration of $\mathrm{pH}$, enzymatic degradation, and inactivation by interaction with food ingredients may decrease antimicrobial activity during storage.

\section{Antimicrobial activity of yeasts}

Although most of the studies and applications of microbial biopreservation have been focused on LAB, a considerable amount of research has also been dedicated to the use of yeasts for inhibiting the growth of foodborne bacteria and fungi (Liu, Sui, Wisniewski, Droby, \& Liu, 2013a). Yeasts are eukaryotic microorganisms, usually defined as unicellular fungi that colonize natural environments such as human, animal and plants tissues, soil and aquatic environments, and food products (Spencer \& Spencer, 2013). The colonization of such vast ecosystems is related to their ability to proliferate and survive in demanding conditions (Sharma, Singh, \& Singh, 2009).

Yeasts have been used extensively in agriculture, biotechnological processes, food industry, and medical applications. Historically, yeasts took part in one of the oldest biopreservation technologies, the process of fermentation used for the production of commodities such as wine, beer, cider, bread, cheeses, sausages, and others (Kurtzman, Fell, \& Boekhout, 2011). More recently, yeasts have been regarded as potential biocontrol agents, particularly for the control of postharvest diseases of fruit and vegetables (Kurtzman et al., 2011; Liu et al., 2013a). Yeasts have a broad antimicrobial spectrum, are genetically stable, have relatively low nutritional requirements, are effective at low concentrations, capable of surviving in adverse conditions of temperature and oxidative stress and are environmentally friendly. The use of yeasts in postharvest disease control is particularly advantageous as yeasts occur naturally on the surface of fruits and vegetables, can colonize wounds for long periods of time, and are minimally affected by pesticides (Barkai-Golan 2001).

Postharvest disease control is still not completely understood but is commonly assumed that it involves interactions between antagonists, pathogens, host, and environment (Nunes, 2012). The central mechanism of yeasts antimicrobial action is competition for available nutrients and space (Droby, Chalutz, Wilson, \& Wisniewski, 1989; Liu et al., 2013a). Other possible modes of action against pathogens include: the attachment to pathogens and secretion of lytic enzymes (Bar-Shimon et al., 2004; Chan \& Tian, 2005; El-Ghaouth, Wilson, \& Wisniewski, 1998; Vivekananthan, Ravi, Ramanathan, \& Samiyappan, 2004); the production of an- timicrobials (Arrarte, Garmendia, Rossini, Wisniewski, \& Vero, 2015; Di Francesco, Ugolini, Lazzeri, \& Mari, 2015; Huang et al., 2011) and the induction of plant defenses against pathogens, such as production of inhibitors of plant cell wall degrading enzymes, antifungal compounds, active oxygen species, and changes of tissue structure, which may include protein production (Chan, Qin, Xu, Li, \& Tian, 2007; Droby et al., 2002; Hershkovitz et al., 2012; Ippolito, El Ghaouth, Wilson, \& Wisniewski, 2000). Also, $\mathrm{pH}$ changes in the medium, as result of organic acid production (Kamzolova, Shishkanova, Morgunov, \& Finogenova, 2003), production of ethanol (Golubev, 2006), depletion of iron, which is an essential nutrient for pathogens (Calvente, Benuzzi, \& de Tosetti, 1999; Saravanakumar, Ciavorella, Spadaro, Garibaldi, \& Gullino, 2008; Sipiczki, 2006), and mitigation of oxidative damage of the fruit host (Xu, Qin, \& Tian, 2008) can decrease spoilage.

Antagonistic action of some yeasts also includes the production of secondary metabolites known as killer toxins or mycocins (Golubev, 2006; Marquina, Santos, \& Peinado, 2002; Suzuki, Ando, \& Machida, 2001). Mycocins are extracellular proteins that act by interrupting cell division and by blocking DNA synthesis (Klassen $\&$ Meinhardt, 2005) or by provoking hydrolysis of cell wall component $\beta$-1,3-glucan (Comitini, Mannazzu, \& Ciani, 2009; Marquina et al., 2002) thus leading to ion leakage by the formation of channels in cytoplasmatic membrane (Ahmed et al., 1999; Kagan, 1983; Santos, San Mauro, Abrusci, \& Marquina, 2007; Schmitt \& Breinig, 2002). This phenotype was first found in brewing strains of S. cerevisiae (Bevan and Makower 1963), and since then has shown to occur in a vast number of yeast genera and environments, including Candida, Cryptococcus, Debaryomyces, Kluyveromyces, Pichia, Torulopsis, Williopsis, and Zygosaccharomyces (Magliani, Conti, Gerloni, Bertolotti, \& Polonelli, 1997; Marquina, Barroso, Santos, \& Peinado, 2001; Schmitt \& Breinig, 2002; Suzuki et al., 2001). Among mycocin-producing yeast, Wickerhamomyces anomalus (previously named Pichia anomala) has been one of the most studied, because it produces high levels of mycocins with a wide range of activity (Muccilli, Wemhoff, Restuccia, \& Meinhardt, 2013; Walker, 2011). Application of killer yeasts, defined as yeasts that are able to produce mycocins, has been reported in the control of postharvest disease in fruits and vegetables (Grzegorczyk, Żarowska, Restuccia, \& Cirvilleri, 2017; Lima et al., 2013; Parafati, Vitale, Restuccia, \& Cirvilleri, 2015; Platania, Restuccia, Muccilli, \& Cirvilleri, 2012; Santos, Sánchez, \& Marquina, 2004), but also in the prevention of spoilage in yogurt (Liu \& Tsao, 2010; Lowes et al., 2000) and cheese (Goerges, Aigner, Silakowski, \& Scherer, 2006; Liu \& Tsao, 2009b). Killer strains were also used for fermentation processes including olive fermentation (Hernández et al., 2008; Llorente, Marquina, Santos, Peinado, \& Spencer-Martins, 1997) and beer and sake production (Hammond \& Eckersley, 1984; Yoshiuchi, Watanabe, \& Nishimura, 2000).

Since the 1st time that the use of a microbial antagonist was reported by Tronsmo and Denis (1977), where they used Trichoderma spp. to control Botrytis cinerea and Mucor mucedo in strawberries, many antagonistic types of yeast have been identified and applied for antimicrobial purposes. Citrus fruits are particularly susceptible to colonization by various fungi, especially Penicillium species. Several studies document the use of yeasts as biocontrol agents in citrus fruits. For instance, Droby et al. (2002) used Candida oleophila for inducing resistance of grapefruit against Penicillium digitatum; Wilson \& Chalutz (1989) conducted a study with over 100 isolates against $P$. digitatum and Penicillium italicum on citrus fruits; 
and Arras, Cicco, Arru, and Lima (1998) tested the antagonistic ability of 19 isolates against P. italicum on artificially wounded citrus fruits and verified that Pichia guilliermondii reduced the infection in $98 \%$. Decay control of citrus fruits was also reported with the use of $W$. anomala (Aloui et al., 2015; Platania et al., 2012), Pantoea agglomerans (Teixidó et al., 2001; Torres et al., 2007, 2011), Kloeckera apiculata (Liu, Luo, \& Long, 2013b; Long, Deng, \& Deng, 2007; Long, Wu, \& Deng, 2005), Pichia membranaefaciens (Luo, Zhou, \& Zeng, 2013; Zhou, Ming, Deng, \& Zeng, 2014), and D. hansenii (Chalutz \& Wilson, 1990; Hernández-Montiel, Ochoa, Troyo-Diéguez, \& Larralde-Corona, 2010; Taqarort et al., 2008), among others. Also, pome fruits are suitable for biocontrol strategies, with numerous works reporting successful approaches. Control of decay in apples and pears caused by $B$. cinerea and Penicillium expansum was reported with antagonistic yeasts such as $C$. oleophila (Wisniewski, Droby, Chalutz, \& Eilam, 1995), Candida sake (Viñas, Usall, Teixidó, \& Sanchis, 1998), Candida saitoana (ElGhaouth et al., 1998), Cryptococcus albidus (Fan \& Tian, 2001; Tian, Fan, Xu, \& Liu, 2002), Metschnikowia pulcherrima (Saravanakumar et al., 2008; Spadaro, Garibaldi, \& Gullino, 2004), P. agglomeran (Morales, Sanchis, Usall, Ramos, \& Marín, 2008; Nunes, Usall, Teixidó, Fons, \& Viñas, 2002), P. guilliermondii (Zhang, Spadaro, Garibaldi, \& Gullino, 2011), P. anomala (Haïssam, 2011), and Rhodotorula glutinis (Benbow \& Sugar, 1999; Zhang et al., 2009). Biocontrol by yeast has similarly been described in stone fruits against B. cinerea, Monilinia fructicola, Rhizopus stolonifer, and $P$. expansum (Qin, Tian, Xu, Chan, \& Li, 2006; Qing \& Shiping, 2000; Yao \& Tian, 2005; Zhang, Zheng, \& Yu, 2007b). Studies with other fruits such as banana (Lassois, de Lapeyre de Bellaire, \& Jijakli, 2008), papaya (Lima et al., 2013), strawberry (Cai, Yang, Xiao, Qin, \& Si, 2015; Zhang et al., 2007a), grapes (Masih \& Paul, 2002; Parafati et al., 2015; Santos \& Marquina, 2004), kiwi (Batta, 2007), and pineapple (Reyes, Rohrbach, \& Paull, 2004) and vegetables as tomatoes (Kalogiannis et al., 2006; Saligkarias, Gravanis, \& Epton, 2002), chillies (Chanchaichaovivat, Ruenwongsa, \& Panijpan, 2007), and potatoes (Schisler, Slininger, $\&$ Bothast, 1997) also demonstrated the potential of yeasts as antagonists.

Besides controlling postharvest diseases of fruits and vegetables, some yeast species have shown potential to control microbial contamination in vinification processes. In this context, de Ullivarri, Mendoza, and Raya (2014) characterized the killer activity of two $S$. cerevisiae strains in the winemaking process. Santos, Navascués, Bravo, and Marquina (2011) tested 39 killer yeasts against Brettanomyces bruxellensis, a species that affects wine quality and concluded that activity of Ustilago maydis was effective against the contaminant species, but did not affect the fermentative ability of S. cerevisiae, thus proving to be a useful tool for biocontrol in wine fermentation. Ciani and Fatichenti (2001) used a killer toxin of Kluveromyces phaffi as a fungicidal in winemaking, with results comparable to that of sulfur dioxide. Later, Comitini and Ciani (2011) investigated the same killer toxin against Brettanomyces/Dekkera yeasts that are known to cause turbidity and off-flavors in wine, showing that the purified killer toxin has fungicidal effects under the physicochemical conditions of winemaking. Also in wine, it was shown that some killer yeasts were effective against strains of Zygosaccharomyces, but did not affect S. cerevisiae (Alonso, Belda, Santos, Navascués, \& Marquina, 2015). Killer toxins producing yeasts have also been employed in cheese making processes. Liu and Tsao (2009b) documented that in cheese inoculated with Williopsis saturnus since the growth of galactose-fermenting yeasts was inhibited. Also, some strains of D. hansenii demonstrated an- tagonistic ability against molds in the preservation of yogurt and cheese (Liu \& Tsao, 2009a).

Antagonistic yeasts may also be used to control the development of molds in cereal grains and consequently, lead to the reduction of mycotoxin contamination. Mycotoxins are secondary products of fungal metabolism that can cause serious health hazards, and their presence in food and feed should be reduced as much as possible. P. anomala has been shown to control spoilage of feed grains by Penicillium roqueforti (Druvefors, Jonsson, Boysen, \& Schnürer, 2002; Druvefors, Passoth, \& Schnurer, 2005). Different dried formulations of this yeast have also been referred to control Penicillium verrucosum and ochratoxin A (OTA) contamination in stored wheat (Mokiou \& Magan, 2008). Other yeasts have also shown abilities to reduce fungal and mycotoxin contamination in cereal crops: Crytococcus nodaensis has been shown to inhibit Fusarium species (Khan, Schisler, Boehm, Slininger, \& Bothast, 2001); S. cerevisiae reduced OTA contamination from isolates of $P$. verrucosum (Petersson, Hansen, Axberg, Hult, \& Schnürer, 1998); P. guilliermondii reduced the growth of $P$. roqueforti in wheat inoculated with $10^{6}$ yeast CFU/g (Petersson \& Schnürer, 1995); among other examples.

The successful use of antagonistic yeast in laboratory experiments had lead agrochemical companies to develop commercial microbial antagonists. Different products have already reached the market. Some examples are: Aspire ${ }^{\mathrm{TM}}$ (C. oleophila) and Yieldplus $^{\mathrm{TM}}$ (C. albidus), both withdrawn due to inconsistent efficacy; Shemer ${ }^{\mathrm{TM}}$ (Metschnikowia fructicola) for various fruits and vegetables; Candifruit ${ }^{\mathrm{TM}}$ (C. sake) for pome fruit and grapevine, and BoniProtect ${ }^{\mathrm{TM}}$ (Aureobasidium pullulans) for wound pathogens developing in apples (Spadaro \& Droby, 2016).

Yeasts used for biocontrol can encounter a great diversity of conditions that can limit their efficiency and affect their viability. Incorporation of microbial antagonists in films or coatings could be useful in improving the biocontrol strategies.

\section{Use of Edible Films and Coatings as Carriers of Living Microorganisms}

The efficiency (nutraceutical or antimicrobial) of both bacteria and yeasts can be compromised by several factors, thus new strategies need to be explored to increase their functionality. The use of edible coatings or films is a possible solution to overcome these limitations since they can reduce the diffusion of active compounds within the food matrix, thus maintaining a suitable concentration on the surface of the food product, but also guaranteeing a higher stability of the microorganisms that are entrapped in the film matrix. A scheme illustrating the main characteristics of edible films and coatings that incorporate living microorganisms is shown in Figure 1.

\section{Bacteria}

So far, only a few works combined edible films and coatings with the probiotic activity of bacteria. The possibility of using an edible matrix as carrier for viable probiotics can lead to better survival rates during storage and consumption, improve sensorial characteristics, better control of probiotic dosage and new applications in food products. The use of edible films or coatings to entrap cells can make application of probiotics in foods easier and less expensive. In fact, the use of edible films and coatings appear as an alternative to encapsulation techniques.

By contrary, the encapsulation of microorganisms is a wellestablished technique that has well-known advantages. The encapsulated microorganisms are easier to handle than in suspension, 

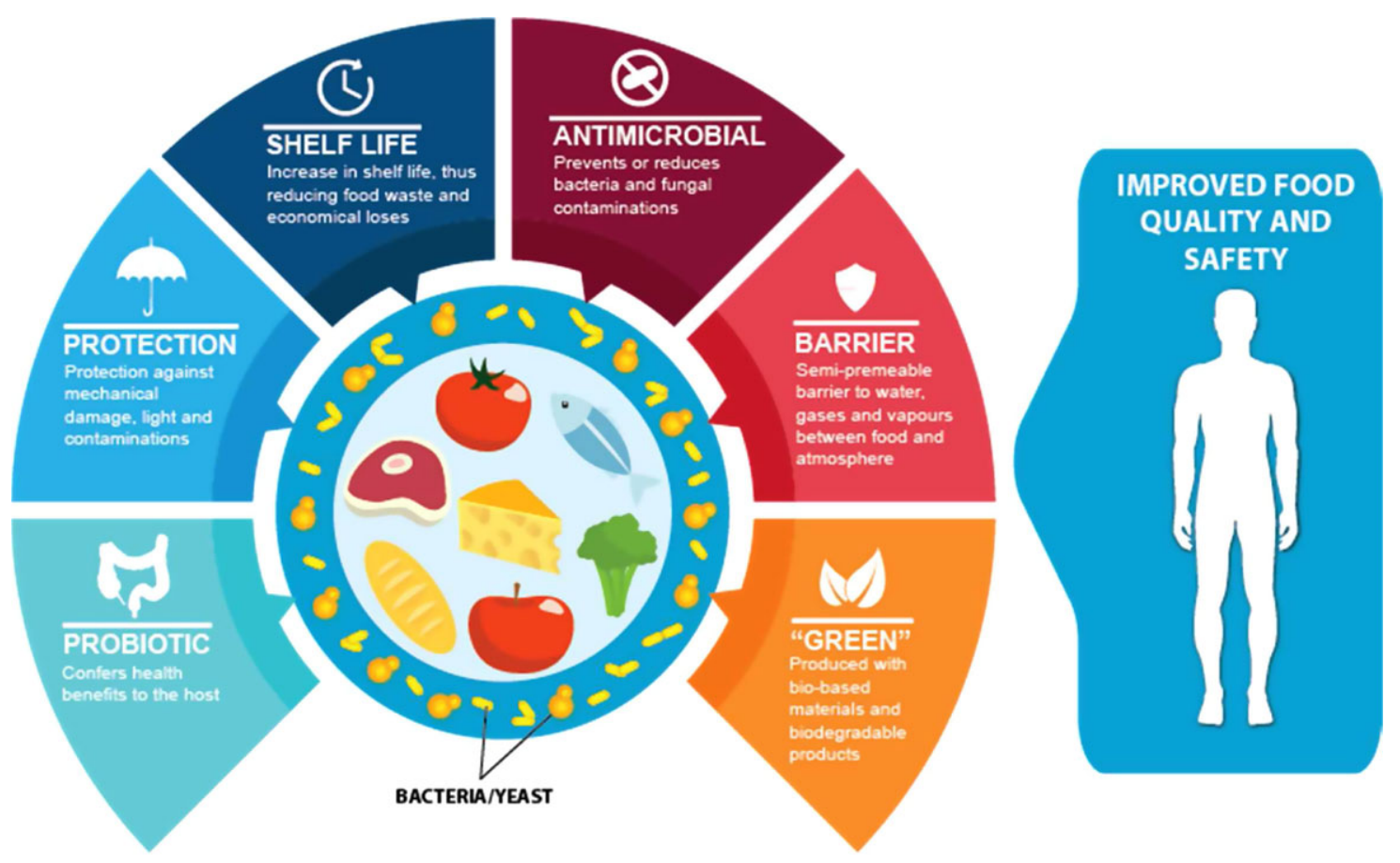

Figure 1-Summary of benefits and advantages of edible films and coatings containing living microorganisms.

the number of encapsulated microorganisms can be quantified to control the administration doses, and it is possible to incorporate protective components that enhance cell survival. Several dispersion methods for the encapsulation of living microorganisms have been used. The most common is spray drying, an atomization method where a cell solution and a dissolved polymer matrix are pressured and atomised into a drying chamber that receives an infusion of hot gas to evaporate the solvent. This procedure is fast and has a low cost. However, the use of high temperatures impairs the survival of microbes. The stress induced by temperature and phase changes tend to damage cell membranes, causing microorganisms to lose, in general, their activity after a few weeks of storage at room temperature (Anal \& Singh, 2007). To overcome this disadvantage termoprotectors or growth promoting factors can be added to the media before the spray drying (Conrad, Miller, Cielenski, \& de Pablo, 2000; Desmond, Ross, O'Callaghan, Fitzgerald, \& Stanton, 2002) or less aggressive methods such as spray freeze-drying or electrospray can be used. Several authors have described successful applications of encapsulated microorganisms in food products, in general using probiotics. Yogurt (Adhikari, Mustapha, Grün, \& Fernando, 2000; Iyer \& Kailasapathy, 2005; Kailasapathy, 2006; Sultana et al., 2000), cheese (Amine et al., 2014; Darukaradhya, Phillips, \& Kailasapathy, 2013; Gardiner et al., 2002), ice-cream (Homayouni, Azizi, Ehsani, Yarmand, \& Razavi, 2008; Shah \& Ravula, 2000), fruit juices (Doherty et al., 2012; Nualkaekul, Cook, Khutoryanskiy, \& Charalampopoulos, 2013; Yinga et al., 2013), sausages (Muthukumarasamy \& Holley, 2006; Muthukumarasamy \& Holley, 2007), and chocolate (Malmo, Storia, \& Mauriello, 2013; Possemiers, Marzorati, Verstraete, \& Wiele, 2010) are examples of products where it was demonstrated that the encapsulation of bacteria improved their survival rate, and in most cases food products maintained their overall sensory characteristics. Nonetheless, in those cases, the encapsulated cells were added to food matrices aiming at their probiotic activity to take place in human body. As far as we know, their use as a biopreservation agent is not explored, besides their direct use in foods. In this context, the use of edible films and coatings can be highly advantageous.

The first author to incorporate probiotic bacteria into edible coatings was Tapia et al. (2007). The objective of their work was to develop alginate and gellan based edible coatings with Bifidobacterium lactis $\mathrm{BB}-12$, in an attempt to coat apple and papaya portions. Water vapor permeability (WVP), thickness, water solubility and swelling ratio of produced edible coatings were determined, as well as the viability of Bifidobacteria in coated fruits. It was found out that the addition of probiotic causes an increase in spacing between the polymer chains and thus promoting diffusivity through the coatings, which accelerated water loss. B. lactis BB-12 population remained viable during $10 \mathrm{~d}$ of storage at $2{ }^{\circ} \mathrm{C}$, with values remaining between $10^{6}$ and $10^{7} \mathrm{CFU} / \mathrm{g}$. Authors concluded that alginate- and gellan-based edible coatings were efficient in supporting probiotics on fresh-cut fruits. However, the water vapor resistance of coatings was $40 \%$ to $50 \%$ lower than the coatings without Bifidus, which increased 20 times the WVP of coatings with the bacteria. Despite coating being helpful in maintaining appropriated concentrations of cells to exert probiotic activity, barrier properties of the coating were compromised with the inclusion of cells (Tapia et al., 2007).

Later, Altamirano-Fortoul et al. (2012) tested the incorporation of probiotics in bread. The incorporation of viable cells in bread had additional difficulties due to the high temperatures of the baking process. This work determined the feasibility of several functional coatings applied to partially baked bread before full baking and the survival of $L$. acidophilus after baking and also during $24 \mathrm{hr}$ of storage. In some of the treatments tested, bacteria were encapsulated by spray drying, before incorporation in edible coatings. Then, several coating treatments and layers were applied to the bread surface. In the first treatment the bread was merely 
coated with a starch solution $(5 \%, \mathrm{w} / \mathrm{v})$ containing $L$. acidophilus microcapsules $(1 \%, \mathrm{w} / \mathrm{v})$; in the 2 nd treatment the same coating with the microcapsules was applied and then a protective layer was added using a starch solution $(5 \%, \mathrm{w} / \mathrm{v})$; finally, in the $3 \mathrm{rd}$ treatment a sandwich like coating consisting of a layer of starch, a layer of dispersed microcapsules $(2 \% \mathrm{w} / \mathrm{w})$, and another layer of starch was done. The authors found out that the incorporation of microcapsules within the coating interrupts the starch-based film structure leading to a decrease in the mechanical resistance. Free bacteria were not observed in the applied coatings, suggesting that the rough surface of the coatings protect probiotics. L. acidophilus remained viable after the baking process in all the coatings, and no differences in taste, moisture content, water activity, or texture properties of the crumb were detected when the coating was applied. In the crust, coatings significantly increased water activity and decreased the mechanical properties associated to crispness. Results also showed that starch coatings were able to protect the microcapsules during baking and storage time. Thus, microencapsulated probiotics were incorporated in edible coatings, leading to bread with similar characteristics to standard bread, but with additional health benefits (Altamirano-Fortoul et al., 2012).

Also, López de Lacey, López-Caballero, Gómez-Estaca, GómezGuillén, and Montero (2012) conducted a study to design an edible structure incorporating probiotic bacteria (L. acidophilus and Bifidobacterium bifidum) and evaluated the survival of the bacteria in those films/coatings. A gelatin-based solution was used to prepare the film/coatings, using sorbitol and glycerol as plasticisers. Results showed that both bacteria species remained viable, both in films and coatings. When applied to fish, counts of viable bacteria within the coating remained practically constant during a storage period of 13 days. Also, it was found that a $2 \log$ cycle reduction of hydrogen sulfide-producing microorganisms involved in fish spoilage was achieved with coatings, either incorporating or not the probiotic bacteria. When a high-pressure treatment was applied (to avoid the modification of the sensory characteristics of fish and remove Gram-negative microorganisms), both counts of LAB and Bifidobacterium remained unaffected. Moreover, application of films containing LAB (pressurized or not) inhibited the growth of Photobacterium phosphoreum, an active microorganism involved in the spoilage of fish. With this study, it was concluded that gelatin edible coatings and films could act as a matrix to incorporate $\mathrm{LAB}$ since they remained viable for 13 days (López de Lacey et al., 2012).

In the following study, López de Lacey, López-Caballero, and Montero (2014), reported the joint incorporation of probiotic bacteria with a phenolic compound. Agar was used as the film matrix to incorporate L. paracasei and Bifidobacterium animalis subsp. lactis and/or green tea extract. Films were tested in fish (hake) during refrigerated storage and changes in microbiologic presence were evaluated. Fish containing probiotics showed an increase in lactic flora after 2 days, which indicates that probiotics may pass from film to muscle. A delay was verified in early days of storage, in Enterobacteriaceae growth in fish covered with films containing probiotics. Films with green tea extract (both with or without probiotics) were able to delay microbial growth most efficiently. Thus, green tea seems to be the primary responsible for the inhibition, especially for psychotropic organisms. Films incorporating both probiotics and green tea extract resulted in differences of 4 log cycles compared to controls, for Enterobacteriaceae. However, after $10 \mathrm{~d}$ this effect was lost over time probably due to adaptation or development of resistance to the extract. The application of green tea extract did not lead to a change in films color, which remained stable during storage time. The conclusion of the study stated that the joint presence of probiotics and green tea could have an additive effect in controlling microbial population and this combination could extend shelf life of hake for more than a week (López de Lacey et al., 2014).

In another work, Kanmani and Lim (2013) formulated edible films based on pullulan and starch, with the addition of several probiotic strains. Pullulan and different starches (potato, tapioca, and corn) were mixed in several ratios with a probiotic cell suspension (L. plantarum, L. reuteri, and L. acidophilus). The addition of probiotic bacterial strains decreased the viscosity and $\mathrm{pH}$ of all film-forming solutions. Also, incorporation of cells resulted in a lower degree of transparency than control films, since cells into the films could obstruct the passage of light. Contrary to Tapia et al. (2007) findings, the addition of cells into pullulan film resulted in significant reduction of WVP, whereas starch-containing films displayed little effect on the WVP of the films. Also, no significant decreases in initial cell viability were observed in films during the drying process and storage at room temperature, except in starch films. Cell viability was maintained up to 20 days, being more stable at $4{ }^{\circ} \mathrm{C}$. The pure pullulan film and the film of an equal mixture of pullulan and potato starch retained the relative cell viability above $80 \%$, even after 30 days in refrigerated conditions. When mechanical properties of the films were studied, pure pullulan film was found to exhibit higher tensile strength than blends of pullulan/starch films. However, the addition of cells into the pure pullulan film resulted in a significant reduction of its tensile strength. The starch-containing pullulan films were relatively less affected by the presence of probiotic cells. Authors concluded that the incorporation of cells could affect mechanical properties of edible films and that pure pullulan and a mixture of pullulan and starch films retained high cell viability during the period of storage, especially when refrigerated (Kanmani \& Lim, 2013).

In another work, Romano et al. (2014) proposed the development of methylcellulose films with the addition of fructooligosaccharides (FOS) as probiotic carriers, in order to protect probiotic cells of heating and drying steps that take part of the producing process of those films. FOS also have prebiotic activity, which adds a new functionality to these films. Strains of Lactobacillus delbrueckii subsp. Bulgaricus, and L. plantarum were incorporated in methylcellulose films, and the effect of FOS in the film and the viability of incorporated probiotic strains were evaluated. In dehydration steps of film formation, FOS had an evident protective effect at $3 \%(\mathrm{w} / \mathrm{v})$. Scanning electron microscopy (SEM) images depicted homogeneity of the films and normal morphology of the cells. The dynamic mechanical analysis determined that addition of FOS alter the hydrogen bonds in polymer molecules, lowering glass transition temperature, thus indicating the plasticiser effect of FOS. Viability studies indicate that L. plantarum can be stored for more extended periods at high relative humidity than $L$. delbrueckii subsp. bulgaricus. The inclusion of FOS was suggested to be a suitable strategy to preserve LAB in films, including those that are sensitive to dehydration (Romano et al., 2014).

In another approach, Tavera-Quiroz et al. (2015) also used methylcellulose films to incorporate a strain of L. plantarum and similarly added FOS (isomalt) as protective and prebiotic. Films were applied in apple snacks, and bacterial resistance in simulated gastrointestinal conditions was evaluated, along with other film parameters. After 90 days of storage at $20{ }^{\circ} \mathrm{C}$, bacterial viability decreased by $1.4 \log \mathrm{CFU} / \mathrm{g}$, but the minimum quantity of probiotics required to exert benefit to the consumer $\left(7 \times 10^{9}\right.$ to 2 $\times 10^{8} \mathrm{CFU} / \mathrm{g}$ ) was still maintained. When exposed to simulated 
gastric conditions, immediately after producing the snack, viability decreased $1.5 \mathrm{log} \mathrm{CFU} / \mathrm{g}$ and following exposure to simulated intestinal digestion did not produce further alterations in the probiotic viability. When apple snacks were stored for more than 30 days, a decrease of viability was more accentuated after gastric and intestinal digestion. However, apples with 90 days of storage and submitted to both digestions were still capable of supplying sufficient concentration of viable probiotics to exert a beneficial effect. Isomalt was effective in protecting apple tissue, decreasing browning, and was also efficient in retaining ascorbic acid. SEM showed that probiotics were embedded entirely in the film matrix, without altering its normal conformation. In the sensory evaluation of the food product, taste, and texture scores were lower in the coated snacks containing probiotics; however, overall acceptability scores for the coated and control snacks were not significantly different (Tavera-Quiroz et al., 2015).

Pereira et al. (2016) developed whey protein isolate (WPI) films incorporating $L$. casei or $B$. animalis. Cell viability of both probiotic strains decreased significantly, approx. $3 \mathrm{log}$ cycles, in films stored at $23{ }^{\circ} \mathrm{C}$. At $4{ }^{\circ} \mathrm{C}$, the decrease was less accentuated. After 10 days of storage, cell viability was maintained, and at the end of 60 days, there was a reduction of 1 and $2 \log$ cycles for $B$. animalis and $L$. casei, respectively. Nevertheless, both conditions are still within the threshold for probiotic cells to exert beneficial effects. It was hypothesized that WPI had positive effects on the viability of microorganisms by providing nutrients, increasing buffer ability of the medium, thus resulting in a small drop in $\mathrm{pH}$. Probiotic exerted no effects on films' thickness and mechanical properties also, color properties of films were maintained throughout storage period (Pereira et al., 2016).

Soukoulis and co-authors published several works where they tested the incorporation of L. rhamnosus GG in different film matrices (Soukoulis et al., 2014b, 2017; Soukoulis, BehboudiJobbehdar, Yonekura, Parmenter, \& Fisk, 2014a; Soukoulis, Singh, Macnaughtan, Parmenter, \& Fisk, 2016). In one of the studies, they developed a novel approach for the application of edible films in pan bread (Soukoulis et al., 2014b). Two edible films formulation with the incorporation of $L$. rhamnosus GG were applied on the crust of pre-baked bread. The film-forming solution was composed of $1 \%(\mathrm{w} / \mathrm{w})$ sodium alginate or a blend of $0.5 \%(\mathrm{w} / \mathrm{w})$ sodium alginate and $2 \%$ whey protein concentrate. Bacterial cells were suspended in the film forming solutions. Images of bread surface showed that the application of edible films did not modify the main structural aspects of the bread crust. Results implied that whey protein concentrate films provided a better surface coverage of the cells and potentially enhanced their resistance against the toxic extrinsic conditions, such as oxygen and water vapor. It was also found that the viability of bacteria in the drying step was influenced by the composition of the film-forming solution, with alginate films showing lower cell viability. The drying method of the film (convective drying at $60{ }^{\circ} \mathrm{C}$ for $10 \mathrm{~min}$ or $180{ }^{\circ} \mathrm{C}$ for $2 \mathrm{~min}$ ) did not affect the viability of bacteria. During the storage time, samples demonstrated a decrease of the viability of $L$. rhamnosus after $24 \mathrm{hr}$, but in the last 2 days of storage (6th and 7th d) most of systems tested showed a gradual recovery of bacteria viability. Also, the use of these edible films did not alter the textural, flavor, and thermophysical properties of bread crust samples. When bread crust samples coated with probiotic films were tested under simulated gastrointestinal conditions, results showed that viability of L. rhamnosus is predominantly affected by the presence of the film, whereas bread matrix did not influence cell viability significantly, when compared with free cells. Sodium alginate based films provided a higher protection to L. rhamnosus GG than whey protein concentrate based edible films. With these films, a medium-sized slice of bread was able to deliver an appropriate amount of probiotic cells after the in vitro digestion, meeting the minimum amount of viable bacteria required to deliver a probiotic effect on the human host. Thus, these results suggest that the application of films at the final stage of the baking process, followed by a rapid cooling of the bread loaves, is an efficient way of producing probiotic bakery products (Soukoulis et al., 2014b).

In another study, Soukoulis et al. (2014a) combined the use of a probiotic strain in a prebiotic film. Gelatin-prebiotic composite edible films incorporating L. rhamnosus GG were investigated. Inulin, polydextrose, glucose oligosaccharides, and wheat dextrin were used as prebiotics compounds. The addition of probiotics did not produce any significant modification in the structural conformation of the film. The incorporation of prebiotics within gelatin films resulted in a more compact and uniform structure, with no detectable interspaces, suggesting that prebiotics act as fillers in the entangled gelatin network. In probiotic viability throughout the drying of films $\left(37^{\circ} \mathrm{C}\right.$, for $\left.15 \mathrm{hr}\right)$, the addition of glucooligosaccharides and polydextrose provided the highest protection for the cells. However, the addition of inulin and wheat dextrin resulted into an adverse effect. During a storage time of $25 \mathrm{~d}$, cell viability was higher in films containing inulin at both storage temperatures tested $\left(25\right.$ and $\left.4{ }^{\circ} \mathrm{C}\right)$. L. rhamnosus $\mathrm{GG}$ viability was maintained for 63 to 100 days and 17 to 30 days for the systems stored at chilled $\left(4^{\circ} \mathrm{C}\right)$ or room $\left(25^{\circ} \mathrm{C}\right)$ temperature conditions, respectively. These results indicate that the incorporation of prebiotic compounds in edible films containing probiotic cells exerts beneficial effects on the microstructure and stability of immobilized cells (Soukoulis et al., 2014a).

In their third work involving probiotics incorporation in edible film, Soukoulis et al. (2016) studied the impact of adding living cells in the physicochemical and structural properties of starchprotein films and characterized the best starch-protein combinations. Starch-protein films were used because it was considered that they could offer more processing flexibility and improved L. rhamnosus GG viability. It has been reported that protein could potentiate cell survival in the films by scavenging free radicals and supplying nutrients (Burgain et al., 2013; Dave \& Shah, 1998). Of the two starch matrices used, rice starch improved better the viability of $L$. rhamnosus GG when compared with corn starch matrices, at $4{ }^{\circ} \mathrm{C}$. However, no significant differences were noticeable at room temperature. As for the proteins, the use of sodium caseinate produced better results when compared with the other tested proteins, gelatin, and soy protein concentrate. Films without proteins had the worst performance regarding shelf life (here defined as the time required to reach a minimum of $6 \log \mathrm{CFU} / \mathrm{g}$ ). Probiotic films were able to sustain a prolonged shelf life, ranging from 27 to 96 days, at $4^{\circ} \mathrm{C}$. SEM results showed that films are characterized by an irregular but homogeneous structure, and that the addition of protein to the rice starch matrices resulted in more compact films, and therefore, with better barrier and mechanical properties. Probiotic cells were not visible in the film, indicating that they are well integrated into the matrix. The presence of probiotics did not affect the mechanical properties of the films, nor significantly altered their opacity. Starch and protein type influenced tensile strength and extensibility of the films, with rice starch having the lower tensile strength. Adding protein to the film composition resulted in a decrease of WVP, with gelatin having the most noticeable effect. Proteins lead to the formation of more compact and less porous structures, as it could be seen in SEM analysis. 
In their most recent work, Soukoulis et al. (2017) studied the physicochemical properties of different film matrices and related them to the viability of $L$. rhamnosus GG in those films. In accordance with their previous study (Soukoulis et al., 2014b, 2016), it was observed that viability of the probiotic cells, after the film's drying procedure, was significantly influenced by the composition of the film. In this study, the ability of edible films with or without the inclusion of whey protein isolate was evaluated to maintain live probiotic organisms. Polysaccharide-based films (pectin, low and high viscosity sodium alginate, and carrageenan/locust bean gum) had the highest cell mortality, when compared with protein films, after the film's drying process. Also, the addition of whey protein concentrate resulted in a 2.4- to 10-fold increase in viability for all matrices, with the exception of pectin/whey protein isolate blends. This protein increased the $\mathrm{pH}$ of film-forming solutions, which may explain the survival rates of cells in films. SEM images corroborate previous findings (Soukoulis et al., 2014a) and show that biopolymer type influence the structure of films, with carrageenan/locust bean gum showing more compact structures. Nonetheless, all films showed a dense and packed biopolymer network, indicating good mechanical, and barrier characteristics. Biopolymer type also affected moisture content, with pectin films exhibiting highest moisture content. Once more, results showed that addition of protein, in this case, whey protein concentrate, decreased WVP of films significantly, thus improving barrier properties. This addition also had an impact on the optical properties of the film, increasing both yellow and red hues and film opacity. Again, film opacity was not affected by the inclusion of probiotics. As expected, viability studies showed that film composition has a significant influence on the inactivation of L. rhamnosus GG and that viability was higher in chilling conditions that at room temperature. Carrageenan/locust bean gum and high viscosity sodium alginate based films performed better at maintaining cells biological activity than the other films formulations. Supplementation of all film formulations with whey protein increased L. rhamnosus GG storage viability from 0.183 to $0.279 \mathrm{log}$ average CFU/day. As referred previously, whey protein can partially reduce osmotic damage to the cells and enhance adhesion, leading to an improved survival rate. In conclusion, the principal components analysis indicate that carrageenan/locust bean gum and high viscosity sodium alginate were the best systems and that addition of whey protein improved biological activity of probiotic cells. These systems also possessed excellent mechanical properties for application in food systems (Soukoulis et al., 2017).

LAB can also be incorporated into edible films and coatings with the purpose of controlling pathogens in food systems. The inclusion of viable LAB can lead to the inhibition of pathogens through competition for space and nutrients, and/or through the production of antimicrobial substances. Besides the use of LAB, also yeasts have been incorporated in edible films and coatings in the same perspective of biocontrol. Yeasts are particularly used in the control of postharvest disease in fruits and vegetables, mainly in the decay caused by Penicillium species.

Incorporating cells into edible films and coatings may result in a high spread and concentration of viable microorganisms on the food product surface and, consequently, in a high biopreservation effect. This fact can be due to the decrease in diffusion rate of the cells from the matrix to the product (Gialamas et al., 2010). Also, the use of films and coatings helps in binding the biocontrol agent to the food product, thus maintaining a suitable cell concentration to exert an antimicrobial effect. Despite the large number of publication on antimicrobial activity of edible films, only few works explored the antimicrobial activity of live bacteria cells when immobilized in edible films or coatings (Concha-Meyer et al., 2011; Gialamas et al., 2010; Sánchez-González et al., 2013, 2014).

The first author to test the incorporation of $\mathrm{LAB}$ with the sole propose of biopreservation was Gialamas et al. (2010). They developed an edible film incorporating Lactobacillus sakei and determined its antimicrobial effect against L. monocytogenes. Sodium caseinate was used as a film-forming agent, and L. sakei was added to films either by incorporating cells into the film forming solution before coating or by spraying a bacterial cells suspension on top of a film already prepared. With the addition of bacteria, barrier, and tensile properties of the films were not significantly altered; probably, because of the relatively small mass of the bacterial cells compared to the total mass of the polymeric matrix. Regarding viability, when bacteria were sprayed on the film surface, it was observed a decrease of the population during storage at room temperature. This was not observed for incorporated cells or the sprayed cells at refrigerated temperature $\left(4^{\circ} \mathrm{C}\right)$. When sorbitol was added to film formulation, the viability of the bacterial cells during storage at $25{ }^{\circ} \mathrm{C}$ over a period of 30 days was increased. The antimicrobial activity of the film was tested in fresh beef. $L$. sakei was able to grow, reaching a concentration of $10^{7} \mathrm{CFU} / \mathrm{cm}^{2}$ after $4 \mathrm{~d}$. Films with $L$. sakei conducted to a significant reduction of $L$. monocytogenes presence in beef compared to the control. The antimicrobial effect of $L$. sakei against $L$. monocytogenes has been attributed to lactic acid production or to direct competition for nutrients. In summary, this study demonstrated that the addition of cells into sodium caseinate based films did not alter their physicochemical properties and that the use of this film system against L. monocytogenes resulted in significant inhibition of this pathogen. Thus, this method was considered a viable alternative to improve food safety (Gialamas et al., 2010).

Also, Concha-Meyer et al., (2011) evaluated the inhibitory effect of films containing two strains of Carnobacterium maltaromaticum (a bacteria isolated from smoked salmon) and nisin against L. monocytogenes in smoked salmon. It was determined that antagonistic activity of the two bacteria strains was due to the production of a bacteriocin-like substance. Results showed that the combination of the 2 strains was more efficient than the use of each strain individually. After a storage period of 21 days, there was a significant decrease of inhibitory activity. This decrease was attributed to the death of the bacteria and decrease of nutrients, which impaired the bacteriocin production. In the control film, without cells or nisin, L. monocytogenes grew until reaching $6.4 \mathrm{log} \mathrm{CFU} / \mathrm{cm}^{2}$ after 28 days, at $4{ }^{\circ} \mathrm{C}$. This indicates that the film alone did not inhibit the pathogen. Films containing only nisin $(100 \mathrm{IU} / \mathrm{mL})$ showed a bacteriostatic effect for 14 days, followed by pathogen growth, which indicates that the bacteria developed resistance to nisin. Films with the 2 strains and sprayed with nisin demonstrated a bacteriostatic effect on L. monocytogenes for 21 days at $4{ }^{\circ} \mathrm{C}$ and exhibited significant pathogen inhibition after 28 days. Results show that it is feasible to maintain these strains under stationary growth and producing bacteriocin-like substances in alginate films for 28 days at $4{ }^{\circ} \mathrm{C}$ (Concha-Meyer et al., 2011).

Antilisterial effect of films incorporating LAB was, also, investigated by Sánchez-González et al. (2013, 2014). Both works studied the incorporation of a bacteriocin producing strain into the film matrix with the goal of extending the antagonistic effect of the bacteriocin. It has been previously reported that films containing bacteriocins only inhibited the growth of pathogens for a short storage period and that after this period the pathogen 
growth recovers and is identical to bacteriocin-free films (Kristo, Koutsoumanis, \& Biliaderis, 2008). In the 1st study, isolate pea protein, HPMC, methylcellulose, and sodium caseinate-based films were incorporated with $L$. plantarum. The mechanical properties, the viability of $\mathrm{LAB}$ and the bacteriocin production in each film matrix were analyzed. The incorporation of microorganisms did not produce significant changes in the mechanical behavior in protein films but decreased elastic modulus in polysaccharide films. WVP was significantly increased with the addition of LAB, independently of the matrix of the film, being justified by the discontinuities introduced by microorganisms to the film matrix, which made the film more prone to mass transfer of water molecules. On the other hand, the optical properties were not affected, in general, by the incorporation of microorganisms. After one month of storage period at $5{ }^{\circ} \mathrm{C}$, caseinate-based films maintained more than $90 \%$ of the initial microbial population, otherwise in HPMC films viability of LAB strain was null. Sodium caseinate-based films were able to support the production of bacteriocins throughout all the storage period. As for protein pea films, there was a slight increase in bacteriocin concentration, but after $15 \mathrm{~d}$ degradation occurred. In cellulose derived films, cells ceased to produce bacteriocins after a short period of time. Only polysaccharide films containing L. plantarum were effective in controlling Listeria innocua growth. After 3 days, microbial growth was reduced by $2 \log$ cycles. Despite, $L$. plantarum having a lower viability in these matrices, initial bacteriocin production is higher than in protein films, and it is maintained during 30 days. In sodium caseinate-based films, bacteriocin concentration only reaches high levels during extended storage periods, and initial production is quite low. The slow kinetics of bacteriocin production in the 1st storage days favored the growth of $L$. innocua during that period. Thus, it was concluded that kinetics of bacteriocin production is a critical factor for its use in bioactive films (Sánchez-González et al., 2013).

In a subsequent study, the same evaluation of film matrix containing $\mathrm{LAB}$ strains able to produce bacteriocins was performed, but this time strains of $L$. acidophilus and $L$. renteri were used. As expected, the addition of LAB decreased the barrier properties of both methylcellulose and sodium caseinate-based films significantly. With the incorporation of microorganisms, a reduction in the elastic modulus and tensile strength at break was also noticed, with the methylcellulose-based films being more affected. This addition altered the optical properties of the films, but differences were not substantial. Regarding the viability of LAB, sodium caseinate films performed better than methylcellulose films, which is in accordance with the previous study (Sánchez-González et al., 2013). Independently of the film matrix, L. acidophilus had better survival rates than $L$. reuteri, which decreased to $3 \log \mathrm{CFU} / \mathrm{cm}^{2}$ after 5 days of storage. Conclusions regarding the production of bacteriocins were similar to the previous work in which it was determined that the nature of the film matrix affects bacteriocin production, with methylcellulose films presenting the best results. All the film formulations led to a reduction of $L$. innocua growth by approx. $1.5 \log$ cycles at the end of 12 days of storage, with methylcellulose films being more effective during the 1st storage days. Thus, concluding that the inhibitory effect is related to bacteriocin production instead of competitive growth (SánchezGonzález et al., 2014). Table 1 summarizes the works that applied living bacteria in edible films and coatings in both probiotic and antimicrobial applications. The ability of living cells to maintain viability (in days of storage) in edible films and coatings is shown in Figure 2.

\section{Yeast}

Besides the use of LAB, yeasts have also been incorporated in edible films and coatings in the same perspective of biocontrol. Yeasts are particularly used in the control of post-harvest disease in fruits and vegetables, mainly in the decay caused by Penicillium species. Examples of incorporation of yeasts in films or coatings for biocontrol purposes have been reported over the past 20 years. Already in 1994, McGuire and Baldwin (1994) reported the use of C. oleophila in cellulose films to extend the storage of grapefruits. When C. oleophila was incorporated into cellulose formulations (methylcellulose or hydroxypropylcellulose), the population of yeast remained stable in concentrations between $10^{5}$ and $10^{6} \mathrm{CFU} / \mathrm{cm}^{2}$, with hydroxypropylcellulose producing better results than methylcellulose. Storage time was increased by 9 and 11 days for hydroxypropyl and methylcellulose, respectively. However, this extension was not significant since half of the fruits coated with these materials without yeast only decayed substantially after 157 and 151 days. It was also tested the influence of the addition of a preservative into the coatings and authors observed that $C$. oleophila was not adversely affected by the incorporation of $0.15 \%$ potassium sorbate, the maximum concentration allowed in food products.

Potjewijd et al. (1995) also used different formulations of cellulose derivatives-based films (carboxymethylcellulose, hydroxypropylcellulose, or methylcellulose) to incorporate Candida guilliermondii and a species of Debaryomyces. When testing the different cellulose formulations, the films of methylcellulose showed the best results regarding cell viability, being then applied to control the decay in two types of oranges. For "Pineapple" oranges, after 1 week of storage at $16^{\circ} \mathrm{C}$, only methylcellulose coatings with $C$. guilliermondii were able to effectively reduce the decay of oranges, when compared with uncoated fruit. After 2 weeks, all treatments, except the one using the coating alone, were able to control decay. In this storage time, both coatings, with C. guilliermondii and Debaryomyces sp., were as effective as a commercial shellac based coating or as coatings containing imazalil (a fungicide commonly used on citrus fruits). Furthermore, after 3 weeks, only treatments containing imazalil showed significant reduction of decay when compared to the uncoated control. On the sixth week, commercial shellac coating also showed significant differences to the uncoated control. The addition of yeast to methylcellulose-based coatings was only effective in reducing decay for 1 or $2 \mathrm{wk}$, for $C$. guilliermondii and Debaryomyces, respectively. Authors have hypothesized that these alterations in antagonistic effect may be attributed to changes in the microorganisms responsible for the decay. As for "Valencia" oranges, after $4 \mathrm{wk}$, all treatments, except the methylcellulose coating alone, resulted in significant reduction of decay, compared to the untreated oranges. Also, coatings with C. guilliermondii were not significantly different from treatments containing imazalil. Differences in results between the two types of oranges are attributed to the fact that "Pineapple" oranges are more susceptible to decay. The population of C. guilliermondii dropped one log cycle after 1 day of storage and then increased slowly for 20 days, with at least a yeast population of $10^{4} \mathrm{CFU} / \mathrm{cm}^{2}$ for uncoated fruit (application of a water suspension) and with higher populations when yeast was incorporated in methylcellulose coatings (approximately $10^{6} \mathrm{CFU} / \mathrm{cm}^{2}$ ), which suggests a protective effect of the coating. The good survival of C. guilliermondii, combined with its antagonistic effect in naturally contaminated oranges, indicated that these coatings could be used in commercial conditions (Potjewijd et al., 1995). 


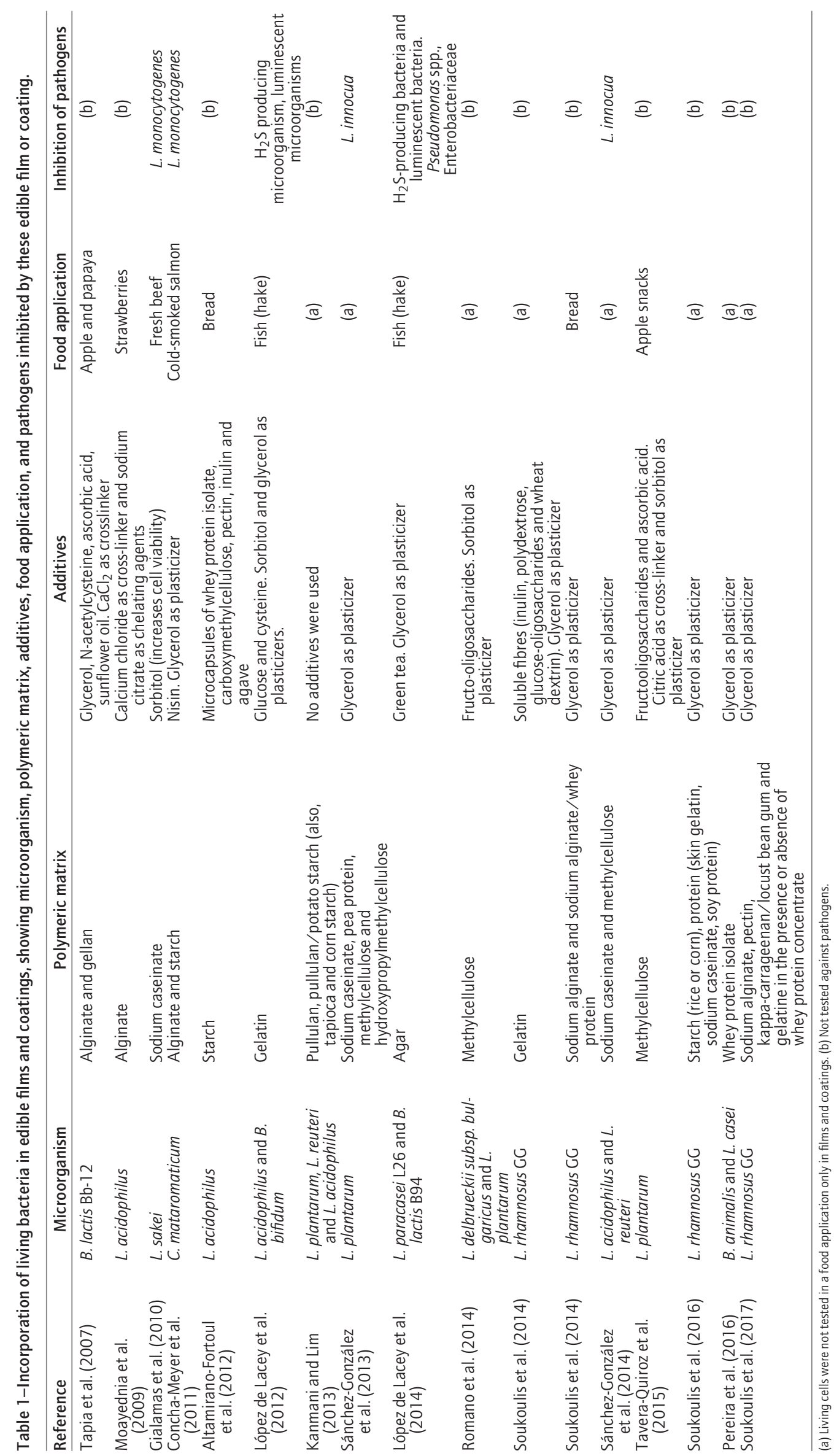




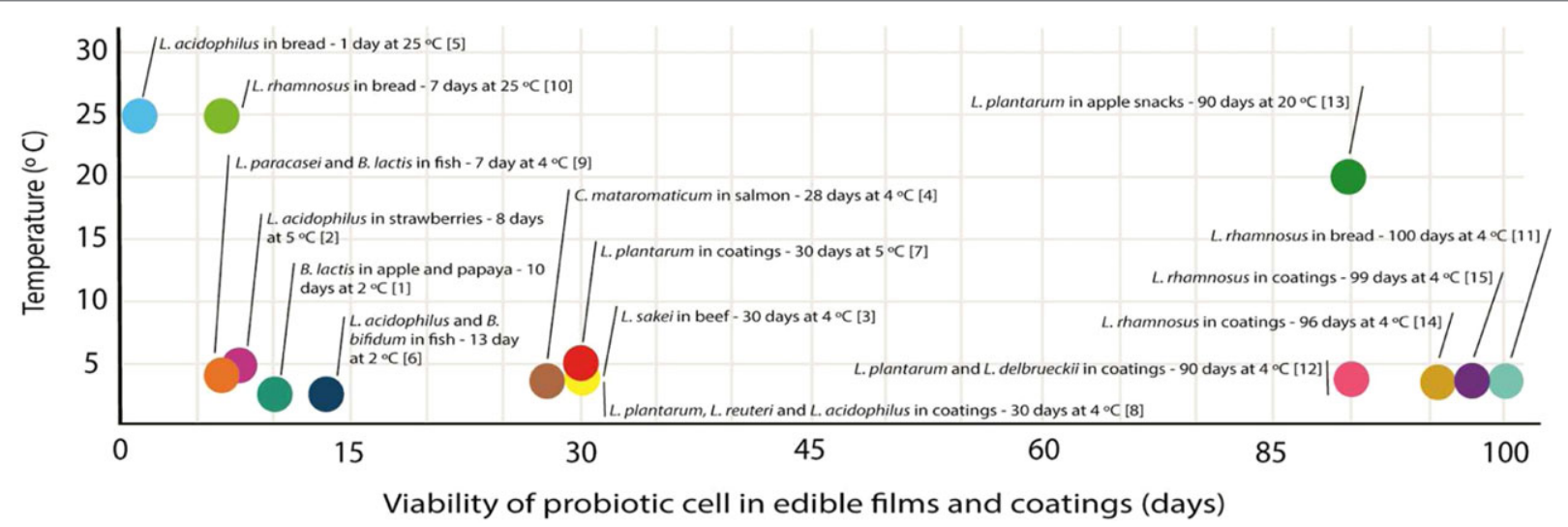

Figure 2-Number of days that probiotic cells can maintain viability (defined as concentrations of viable cells above log $6 \mathrm{CFU} / \mathrm{g}$, CFU/mL or $\mathrm{CFU} / \mathrm{cm}^{2}$ ) in edible films and coatings (applied in food products or not) in function of storage temperature. In works with more than one condition tested, only best results are shown. Ref. [1] Tapia et al., 2017; [2] Moayednia et al. 2009; [3] Guilamas et al., 2010; [4] Concha-Meyer et al., 201 1; [5] Altamirano-Fortoul et al., 2012; [6] López de Lacey et al., 2012; [7] Sánchez-González et al., 2013; [8] Kanmani \& Lim, 2013; [9] López de Lacey et al., 2014; [10] Soukoulis et al., 2014; [11] Soukoulis et al., 2014; [12] Romano et al., 2014; [13] Tavera-Quiroz et al., 2015; [14] Soukoulis et al., 2016; [15] Soukoulis et al., 2017.

Another work, McGuire and Hagenmaier (1996), tested the tolerance of C. oleophila to different constituents of the coatings with the aim of developing formulations non-toxic to the yeast. In an aqueous dispersion of shellac latex, C. oleophila remained viable above $97 \%$ after $24 \mathrm{hr}$. Addition of ethanol into this formulation was not toxic at $2 \%$, but at $4 \%$ it caused the death of $90 \%$ of yeast population, in this time period. As for the addition of bases, at a $\mathrm{pH}$ higher than 8.25 , microorganisms death was rapid. This resulted from the incorporation of more than $1.5 \%$ morpholine, $0.3 \%$ ammonia or $1.5 \% \mathrm{KOH}$ in shellac latex formulations. In similar experiments with bleached shellac, all formulations with $\mathrm{pH}$ between 7.1 and 7.7 presented an excellent survival of the microorganisms. Thus, the ability of survival of the microorganisms with the incorporation of bases is mostly determined by $\mathrm{pH}$. With wood resin ester, only the addition of $\mathrm{KOH}$ allowed the microorganism survival above $10^{5} \mathrm{CFU} / \mathrm{mL}$ for $24 \mathrm{hr}$. Several combinations of shellac coatings and ethanol, ammonia, morpholine and oleic acid with $\mathrm{pH}$ ranging between 6.0 and 9.1 were also tested. Three of the shellac formulations with $\mathrm{pH}$ between 6.0 and 8.0 supported yeast populations between $7 \times 10^{4}$ and $5 \times 10^{5} \mathrm{CFU} / \mathrm{mL}$, for over $24 \mathrm{hr}$. Two of those formulations were tested for the survival of yeast in coated grapefruits. The formulation 67A consisted in shellac latex at $\mathrm{pH} 6$ with $0.15 \%$ ethanol, and the formulation 185A of a combination of shellac and shellac ester at $\mathrm{pH} 7.6$ with $4.2 \%$ ethanol, $1.4 \%$ morpholine, and $0.6 \%$ ammonia. The number of yeast in dried surfaces of both coatings decreased from $10^{6}$ to $10^{4} \mathrm{CFU} / \mathrm{cm}^{2}$, after 7 days, with populations in both treatments increasing after that period. Viable microorganisms were maintained between $10^{4}$ and $10^{5} \mathrm{CFU} / \mathrm{cm}^{2}$ for a storage time of 4 months, in the tested formulations. To test decay, grapefruits were placed in a hot air chamber with circulating air at $48{ }^{\circ} \mathrm{C}$ for $3 \mathrm{hr}$. The incorporation of C. oleophila in the coatings increased grapefruit storage by 9 to 14 days, with the 67A coating producing the best results, with a total shelf life of 165 days. Both formulations had better results than a commercial shellac coating. Authors concluded that shellac coatings should contain less than $4 \%$ ethanol and have a $\mathrm{pH}$ lower than 8.25 for a good yeast survival (McGuire \& Hagenmaier, 1996).

In a similar study, McGuire and Dimitroglou (1999) found that survival of C. oleophila was greater when $\mathrm{pH}$ was inferior to 7.6 and that coatings based on sucrose esters were less toxic to the microorganisms, with populations viability above $10^{6} \mathrm{CFU} / \mathrm{mL}$. Substitution of oleic acid with polysorbate as surfactant also improved microorganisms' survival in the tested formulations. Sucrose ester formulations improved more the development of yeast population than shellac-based coatings, leading to a slower decay over the course of 6 months. Also, the shelf life of grapefruits coated with sucrose ester that incorporates the C. oleophila was higher, or at least equal, to fruit treated with the antifungal imazalil (McGuire \& Dimitroglou, 1999).

Sharma et al. (2006) used chitosan films containing Candida utilis for the control of decay in tomatoes caused by Alternaria alternata and Geotrichum candidum. All treatments tested (combinations of chitosan at $0.25 \%$ and $0.5 \%$ with or without C. utilis) significantly decreased both infection (by A. alternata and G. candidum) and the lesion diameter when compared with controls. Combination of chitosan $0.5 \%$ with C. utilis produced the best results. Yeast was able to survive and multiply, increasing from $10^{5}$ to $10^{6} \mathrm{CFU}$ per wound after $168 \mathrm{hr}$ (Sharma et al., 2006).

In their study, Fan et al. (2009) tested the incorporation of Candida laurentii in alginate-based coatings to extend the shelf life of strawberries. After optimization, a formulation containing $2 \%$ glycerol, $0.5 \%$ palmitic acid, $0.5 \%$ glycerol monostearate, and $0.5 \%$ $\beta$-cyclodextrin was chosen based on the performance of the film regarding WVP. After 5 days of storage, a combination of alginatebased films with C. laurentii had 25\% less decay than the control group. These coatings reduced the growth of psychrotrophic microorganisms and also molds. Coatings also prevented fruits weight loss, had a positive effect on the firmness of the fruit and did not affected significantly the external color of strawberries (Fan et al., 2009).

Yinzhe and Shaoying (2013) investigated the effect of carboxymethylcellulose and alginate-based coatings incorporating brewer yeast on grape preservation. After 13 days of storage at room temperature, coatings with brewer yeast at concentrations from $1.5 \times 10^{7}$ to $1.5 \times 10^{9} \mathrm{CFU} / \mathrm{mL}$ reduced decay when compared with uncoated control. Quality of the grape increased with increasing concentration of the yeast, however at $1.5 \times 10^{10}$ $\mathrm{CFU} / \mathrm{mL}$ sensory characteristics of the grapes were altered. As expected, coatings decreased weight loss, and the best results were 


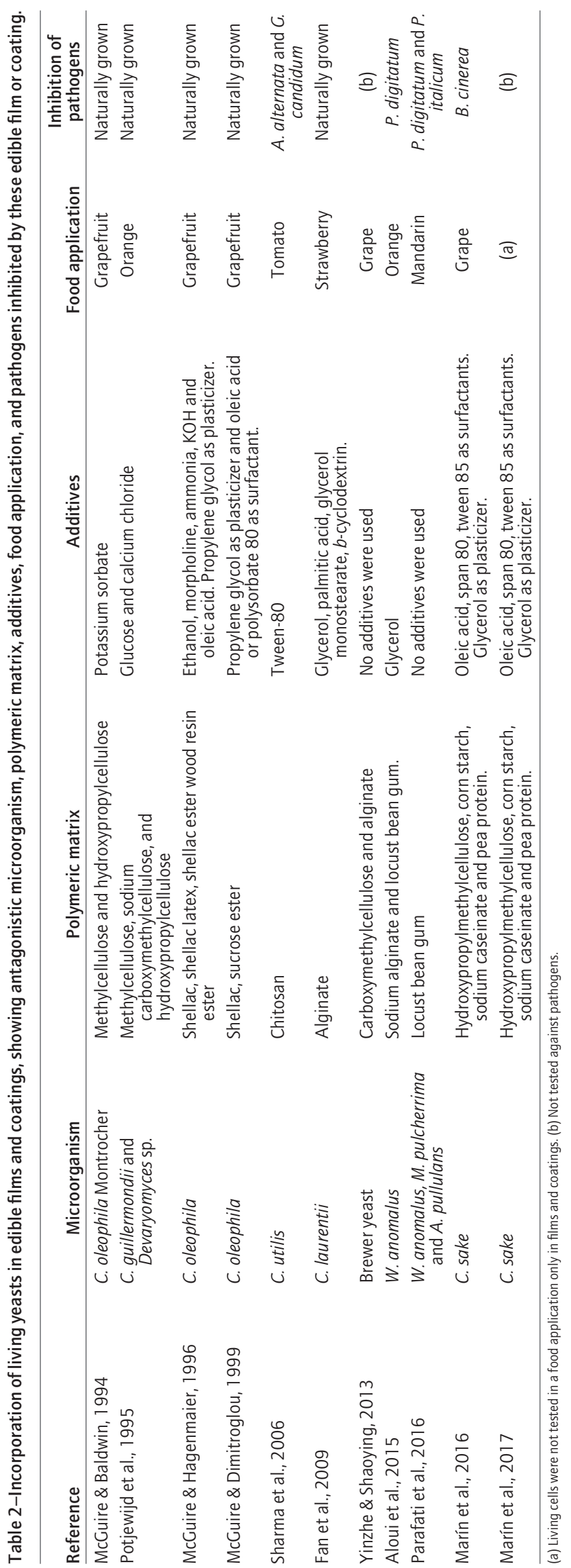

obtained with coatings incorporating the yeast. They also helped to maintain total soluble solids, even though there was a decrease in all samples. Enzymatic activities, superoxide dismutase, peroxidase, and catalase, were higher in coatings with yeast when compared to the uncoated control or coatings without cells. The combined action of these enzymes could eliminate free radicals that accelerate senescence. Coatings with yeast helped to slow the decrease in vitamin $\mathrm{C}$ during the storage time. These results demonstrate that coatings incorporating baker yeast are beneficial to grape preservation (Yinzhe \& Shaoying, 2013).

Aloui et al. (2015) incorporated $W$. anomalus in sodium alginate and locust bean gum based films. The incorporation of $W$. anomalus did not affect the tensile strength, elongation at break, contact angle values and WVP of the films in both alginate and locust bean gum significantly, neither affected gloss of the films. Regarding flexibility and barrier properties, locust bean gum-based films had a better performance than alginate films. When $W$. anomalus was incorporated in the films, no significant changes in viability were observed after 1 week of storage; this indicates that both film formulations were able to maintain the viability of $W$. anomalus, probably due to the ability to provide nutrients. After 14 days, yeast population was reduced by 0.75 and $0.95 \log \mathrm{CFU} / \mathrm{cm}^{2}$ in locust bean gum and alginate films, respectively. Authors have hypothesized that nutrients depletion and a decrease in water content are responsible for this reduction. Until the end of a storage period of 21 days, at $25^{\circ} \mathrm{C}$, no significant decrease in microorganism viability was noticed. Both films formulations were able to maintain $85 \%$ of the initial yeast population. In vitro tests of antifungal activity of the films showed that films incorporating $W$. anomalus inhibit the growth of $P$. digitatum completely and at the same time promoted the growth of yeasts up to $10^{6} \mathrm{CFU} / \mathrm{cm}^{2}$ after 3 days of storage. In addition, they maintained viability until the end of a storage period of 15 days. When applied in oranges, alginate and locust bean gum coatings reduced weight loss in $28 \%$ to $33 \%$ and loss of firmness in more than $21 \%$, after 15 days, when compared with uncoated oranges. Contrary to the findings of Fan et al. (2009), incorporation of yeast did not affect weight loss or firmness of the oranges. Coatings incorporating $W$. anomalus were effective in preventing all $P$. digitatum incidences up to 10 days of storage. In uncoated oranges, all of the samples were infected by the mold after 4 days, and in coated samples, without yeasts, the maximum infection was reached after 5 days. After a storage period of 13 days, decay was reduced by $73 \%$ when compared with uncoated and coated without yeast experiments. Thus, authors concluded that alginate and locust bean gum coatings with $W$. anomalus were effective in controlling mold infection and preserving properties of oranges (Aloui et al., 2015).

Also using locust bean-based coatings, Parafati, Vitale, Restuccia, and Cirvilleri (2016) tested the survival and biocontrol ability of $W$. anomalus, M. pulcherrima, and A. pullulans in coated mandarins. Incorporation of yeasts reduced the incidence of $P$. digitatum significantly in mandarins, with best results obtained by $M$. pulcherrima in a $1 \%$ locust bean gum coating. Similar results were obtained for the incidence of $P$. italicum; however, no significant differences were noticed between coatings with $0.5 \%$ and $1 \%$ locust bean gum. Incorporation in films significantly enhanced the viability of all yeast strains tested (Parafati et al., 2016).

Recently, Marín et al. (2016, 2017) developed two works where they evaluated the incorporation of C. sake in different coating formulations for the coating of grapes. In their first study, HPMC, starch, sodium caseinate, and pea protein were used as primary components in the coatings in combination with different 
surfactants (oleic acid, span 80, and tween 85). Results showed that higher values of microorganisms were obtained with starch, sodium caseinate, and pea protein with the oleic acid formulation. All formulations potentiated the increase of C. sake population after 7 days. Sodium caseinate based coatings with or without surfactants and pea protein with oleic acid and tween 85 had a significantly higher population than all of the other treatments. In general, surfactants did not affect yeast survival, except for pea protein formulations. When evaluating the efficacy of treatments in the control of $B$. cinerea on grapes, it was found that highest reduction of infection was achieved by films composed of starch with tween 85, HPMC with span 80, sodium caseinate, and sodium caseinate with oleic acid, with reductions reaching $80 \%$ after 7 days. With 12 days of incubation, the positive effect on the reduction of infection decreased in all treatments due to further development of the existing infection. Still, some treatments showed a significantly higher reduction than the uncoated control. SEM images showed that starch coatings offered a more significant coverage of the grape surface than sodium caseinate coatings. Surfactants had a disaggregating effect on the cells, which appeared more dispersed, than coatings without surfactants. As a conclusion, the authors stated that film formulations based on starch and sodium caseinate were the most effective in maintaining cell viability and in reducing proliferation of $B$. cinerea (Marín et al., 2016).

In a subsequent study, Marín, Atarés, Cháfer, and Chiralt (2017) used the same film forming materials, as well as the same surfactants, to determine films' characteristics and barrier and optical properties. Starch and sodium caseinate exhibited a good coating capacity, independently of the presence of surfactants, with sodium caseinate exhibiting the highest adhered solid mass. The type of biopolymer affected film gloss, with pea protein films having the highest values. The color of the film was also affected by biopolymer type, with polysaccharides producing lighter films with less saturation, when compared with protein-based films. The thickness of the films ranged between 40 and $65 \mu \mathrm{m}$, with polysaccharides producing thicker films. In general, incorporation of surfactant also led to thicker films. HPMC films showed better barrier properties, due to its hydrophobic nature. Effect of surfactants on WVP was dependent of both surfactant and biopolymers, with oleic acid causing, in general, WVP decrease. As previous authors reported (Aloui et al., 2015; Gialamas et al., 2010), incorporation of cells did not affect the barrier properties of the films significantly. The inclusion of cells caused a decrease in the films' gloss, due to the additional roughness that cells introduced in the films. Cell population was able to increase in protein films during the drying period of $48 \mathrm{hr}$, but there was not a clear pattern of how the presence of surfactants influenced cell viability. After 7 and 14 days of storage, protein films were the best in maintaining C. sake viability, which could be explained by the nutritional effect of proteins on the yeast. When comparing cell survival with their previous study with coatings applied in grapes (Marín et al., 2016), results indicate that grapes affected cell viability, improving their survival and multiplication capacity, when compared with cells entrapped in a standalone film (Marín et al., 2017). A summary of the works that incorporate living yeast in films and coatings is shown in Table 2.

\section{Conclusion and Future Trends}

Edible films and coatings showed to be a good strategy for the carrier of living microorganisms, demonstrating an improvement on probiotic viability during storage time and processing of the food product. The mechanical and physicochemical properties of films and coatings may be affected by the presence of microorganisms, depending on the base material used, as well as plasticisers or other additives. Different methods of incorporation of living microorganisms in the film and coatings can be used (sprayed or incorporated) as well as combinations of films and coatings with microencapsulated microorganisms. Coating procedure also influences the final properties of the films and coatings. Moreover, the materials used influence microorganisms' viability and storage temperature is also a decisive factor in their survival. When applied to food products, in general, the presence of edible films did not modify the sensory characteristics of the product significantly. In general, all studies reported that the use of edible films and coatings is a promising method to confer stability of probiotics during storage time.

In addition, the incorporation of microorganisms with antimicrobial properties was effective in controlling pathogens when films are applied in food products. The combination of materials, microorganisms' incorporation methods, production, microorganism strains, storage conditions, and application into food products can vary and with them can also vary the success of the application of edible films incorporating living microorganisms to prevent or delay contamination of food products. However, further studies are needed to elucidate the influence of all the variables involved in this field of study.

Several new methods are being developed that can potentiate the use of microorganisms in edible films and coatings. A possible example is the conjugation of biocontrol microorganisms with specific compounds or even other microorganisms that may stimulate the secretion of antifungal metabolites, or conjugations that can maintain probiotic populations in numbers that are beneficial for the host. Also, several new formulations are being developed lately, such as those combining films and coatings and emulsions, micro or nano encapsulations or liposomes that can contribute to a homogenous distribution and stability of compounds or microorganisms. Still, extensive research is needed on the new methods of films and coatings formation and microorganism incorporation. With almost infinite combinations of materials, methods, microorganisms, and compounds, many solutions can be developed, each adapted to the food product and the consumer needs.

\section{Acknowledgments}

Ana Guimarães received support through grant SFRH/BD/ 103245/2014 from the Portuguese Foundation for Science and Technology (FCT). Luís Abrunhosa was supported by grant UMINHO/BPD/51/2015 from project UID/BIO/04469/2013 financed by FCT/MEC (OE). This study was supported by FCT under the scope of the strategic funding of UID/BIO/04469/2013 unit and COMPETE 2020 (POCI-01-0145-FEDER-006684), and of BioTecNorte operation (NORTE-01-0145-FEDER000004) funded by European Regional Development Fund under the scope of Norte2020 - Programa Operacional Regional do Norte. Vectors used in Figure were designed by Freepik.

\section{Authors' Contributions}

Ana Guimarães researched studies and wrote the manuscript; Luís Abrunhosa, Lorenzo M. Pastrana, and Miguel A. Cerqueira provided ideas, discussion, and revised and corrected the manuscript. 


\section{References}

Adhikari, K., Mustapha, A., Grün, I. U., \& Fernando, L. (2000). Viability of microencapsulated bifidobacteria in set yogurt during refrigerated storage. Journal of the American Dairy Science, 83, 1946-1951.

Ahmed, A., Sesti, F., Ilan, N., Shih, T. M., Sturley, S. L., \& Goldstein, S. A. N. (1999). A molecular target for viral killer toxin: TOK1 potassium channels. Cell, 99, 283-291.

Alakomi, H. L., Skytta, E., Saarela, M., Mattila-Sandholm, T., Latva-Kala, K., \& Helander, I. M. (2000). Lactic acid permeabilizes gram-negative bacteria by disrupting the outer membrane. Applied and Environmental Microbiology, 66, 2001-2005.

Alonso, A., Belda, I., Santos, A., Navascués, E., \& Marquina, D. (2015). Advances in the control of the spoilage caused by Zygosaccharomyces species on sweet wines and concentrated grape musts. Food Control, 51, 129-134.

Aloui, H., Licciardello, F., Khwaldia, K., Hamdi, M., \& Restuccia, C. (2015). Physical properties and antifungal activity of bioactive films containing Wickerhamomyces anomalus killer yeast and their application for preservation of oranges and control of postharvest green mold caused by Penicillium digitatum. International Journal of Food Microbiology, 200, 22-30.

Altamirano-Fortoul, R., Moreno-Terrazas, R., Quezada-Gallo, A., \& Rosell, C. M. (2012). Viability of some probiotic coatings in bread and its effect on the crust mechanical properties. Food Hydrocolloids, 29, 166-174.

Amine, K. M., Champagne, C. P., Raymond, Y., St-Gelais, D., Britten, M., Fustier, P., ... Lacroix, M. (2014). Survival of microencapsulated Bifidobacterium longum in Cheddar cheese during production and storage. Food Control, 37, 193-199.

Ammor, S., Tauveron, G., Dufour, E., \& Chevallier, I. (2006). Antibacterial activity of lactic acid bacteria against spoilage and pathogenic bacteria isolated from the same meat small-scale facility: 1 - Screening and characterization of the antibacterial compounds. Food Control, 17, 454-461. Anal, A. K., \& Singh, H. (2007). Recent advances in microencapsulation of probiotics for industrial applications and targeted delivery. Trends in Food Science and Technol, 18, 240-251.

Angelov, A., Gotcheva, V., Kuncheva, R., \& Hristozova, T. (2006)

Development of a new oat-based probiotic drink. International Journal of Food Microbiology, 112, 75-80.

Arrarte, E., Garmendia, G., Rossini, C., Wisniewski, M., \& Vero, S. (2015). Volatile organic compounds produced by Antarctic strains of Candida sake play a role in the control of postharvest pathogens of apples. Biological Control, 109, 14-20.

Arras, G., Cicco, V. D., Arru, S., \& Lima, G. (1998). Biocontrol by yeasts of blue mould of citrus fruits and the mode of action of an isolate of Pichia guilliermondii. Journal of Horticultural Science and Biotechnology, 73, 413-418.

Atanassova, M., Choiset, Y., Dalgalarrondo, M., Chobert, J. M., Dousset, X., Ivanova, I., \& Haertlé, T. (2003). Isolation and partial biochemical characterization of a proteinaceous anti-bacteria and anti-yeast compound produced by Lactobacillus paracasei subsp. paracasei strain M3. International Journal of Food Microbiology, 87, 63-73.

Axelsson, L. T., Chung, T. C., Dobrogosz, W. J., \& Lindgren, S. E. (1989). Production of a broad spectrum antimicrobial substance by Lactobacillus reuteri. Microbial Ecology in Health and Diseas, 2, 131-136.

Bar-Shimon, M., Yehuda, H., Cohen, L., Weiss, B., Kobeshnikov, A., Daus, A., ... Droby, S. (2004). Characterization of extracellular lytic enzymes produced by the yeast biocontrol agent Candida oleophila. Current Genomics, $45,140-148$.

Barkai-Golan, R. (2001). Postharvest diseases of fruits and vegetables: Development and control. Amsterdam: Elsevier.

Batta, Y. A. (2007). Control of postharvest diseases of fruit with an invert emulsion formulation of Trichoderma harzianum Rifai. Postharvest Biology and Technology, 43, 143-150.

Benbow, J. M., \& Sugar, D. (1999). Fruit surface colonization and biological control of postharvest diseases of pear by preharvest yeast applications. Plant Disease, 83, 839-844.

Bevan, E. A., \& Makower, M. (1963). The physiological basis of the killer character in yeast. In: Procedings of the International Congress of Genetic (pp. 202-203). Hague, Netherlands.

Bosch, M., Nart, J., Audivert, S., Bonachera, M. A., Alemany, A. S., Fuentes, M. C., \& Cuñé, J. (2012). Isolation and characterization of probiotic strains for improving oral health. Archives of Oral Biology, 57, 539-549.

Braegger, C., Chmielewska, A., Decsi, T., Kolacek, S., Mihatsch, W., Moreno, L., ... van Goudoever, J. (2011). Supplementation of infant formula with probiotics and/or prebiotics: A systematic review and comment by the ESPGHAN committee on nutrition. Journal of Pediatric Gastroenterology and Nutrition, 52, 238-250.

Burgain, J., Gaiani, C., Francius, G., Revol-Junelles, A. M., Cailliez-Grimal, C., Lebeer, S., . . Scher, J. (2013). In vitro interactions between probiotic bacteria and milk proteins probed by atomic force microscopy. Colloids and Surfaces B, 104, 153-162.

Burgain, J., Gaiani, C., Linder, M., \& Scher, J. (2011). Encapsulation of probiotic living cells from laboratory scale to industrial applications. Journal of Food Engineering, 104, 467-483.

Cai, Z., Yang, R., Xiao, H., Qin, X., \& Si, L. (2015). Effect of preharvest application of Hanseniaspora uvarum on postharvest diseases in strawberries. Postharvest Biology and Technology, 100, 52-58.

Calvente, V., Benuzzi, D., \& de Tosetti, M. I. S. (1999). Antagonistic action of siderophores from Rhodotorula glutinis upon the postharvest pathogen Penicillium expansum. International Biodeterioration and Biodegradation, 43, 167-172.

Campos, C. A., Gerschenson, L. N., \& Flores, S. K. (2010). Development of edible films and coatings with antimicrobial activity. Food and Bioprocess Technology, 4, 849-875.

Cerqueira, M. A., Teixeira, J. A. C., \& Vicente, A. A. (2016). Edible packaging today. In M. A. Cerqueira, R. N. C. Pereira, O. L. da Silva, J. A C. Teixeira, \& A. A. Vicente (Eds.). Edible food packaging: Materials and processing technologies. Boca Raton: CRC Press.

Ceugniez, A., Coucheney, F., Jacques, P., Daube, G., Delcenserie, V., \& Drider, D. (2017). Anti-Salmonella activity and probiotic trends of Kluyveromyces marxianus S-2-05 and Kluyveromyces lactis S-3-05 isolated from a French cheese, Tomme d'Orchies. Research in Microbiolog, 168, 575-582.

Chalutz, E., \& Wilson, C. L. (1990). Postharvest biocontrol of green and blue mold and sour rot of citrus fruit by Debaryomyces hansenii. Plant Diseases, 74 134-137.

Chan, Z., Qin, G., Xu, X., Li, B., \& Tian, S. (2007). Proteome approach to characterize proteins induced by antagonist yeast and salicylic acid in peach fruit. Journal of Proteome Research, 6, 1677-1688.

Chan, Z., \& Tian, S. (2005). Interaction of antagonistic yeasts against postharvest pathogens of apple fruit and possible mode of action. Postharvest Biology and Technology, 36, 215-223.

Chanchaichaovivat, A., Ruenwongsa, P., \& Panijpan, B. (2007). Screening and identification of yeast strains from fruits and vegetables: Potential for biological control of postharvest chilli anthracnose (Colletotrichum capsici). Biological Control, 42, 326-335.

Charalampopoulos, D., Pandiella, S. S., \& Webb, C. (2003). Evaluation of the effect of malt, wheat and barley extracts on the viability of potentially probiotic lactic acid bacteria under acidic conditions. International Journal of Food Microbiology, 82, 133-141.

Chung, T. C., Axelsson, L., Lindgren, S. E., \& Dobrogosz, W. J. (1989). In Vitro studies on reuterin synthesis by Lactobacillus reuteri. Microbial Ecology in Health and Disease, 2, 137-144

Ciani, M., \& Fatichenti, F. (2001). Killer toxin of Kluyveromyces phaffi DBVPG 6076 as a biopreservative agent to control apiculate wine yeasts. Applied and Environmental Microbiology, 67, 3058-3063.

Claisse, O., \& Lonvaud-Funel, A. (2000). Assimilation of glycerol by a strain of Lactobacillus collinoides isolated from cider. Food Microbiology, 17, 513-519.

Comitini, F., \& Ciani, M. (2011). Kluyveromyces wickerhamii killer toxin: Purification and activity towards Brettanomyces/Dekkera yeasts in grape must. FEMS Microbiology Letters, 316, 77-82.

Comitini, F., Mannazzu, I., \& Ciani, M. (2009). Tetrapisispora phaffi killer toxin is a highly specific $\beta$-glucanase that disrupts the integrity of the yeast cell wall. Microbial Cell Factories, 8, 55.

Concha-Meyer, A., Schöbitz, R., Brito, C., \& Fuentes, R. (2011). Lactic acid bacteria in an alginate film inhibit Listeria monocytogenes growth on smoked salmon. Food Control, 22, 485-489.

Condon, S. (1987). Responses of lactic acid bacteria to oxygen. FEMS Microbiology Reviews, 3, 269-280.

Conrad, P. B., Miller, D. P., Cielenski, P. R., \& de Pablo, J. J. (2000). Stabilization and preservation of Lactobacillus acidophilus in saccharide matrices. Cryobiology, 41, 17-24.

Cruz, A. G., Antunes, A. E. C., Sousa, A. L.cOP., Faria, J. A. F., \& Saad, S. M. I. (2009). Ice-cream as a probiotic food carrier. Food Research International, 42, 1233-1239.

Czerucka, D., Piche, T., \& Rampal, P. (2007). Review article: Yeast as probiotics - Saccharomyces boulardii. Alimentary Pharmacology \& Therapeutics, $26,767-778$. 
Dainelli, D., Gontard, N., Spyropoulos, D., Zondervan-van den Beuken, E., \& Tobback, P. (2008). Active and intelligent food packaging: Legal aspects and safety concerns. Trends in Food Science \& Technology, 19, S103-S12.

Dal Bello, F., Clarke, C. I., Ryan, L. A. M., Ulmer, H., Schober, T. J., Ström, K., ... Arendt, E. K. (2007). Improvement of the quality and shelf life of wheat bread by fermentation with the antifungal strain Lactobacillus plantarum FST 1.7. Journal of Cereal Science, 45, 309-318.

Dalié, D. K. D., Deschamps, A. M., \& Richard-Forget, F. (2010). Lactic acid bacteria - Potential for control of mould growth and mycotoxins: A review. Food Control, 21, 370-380.

Darukaradhya, J., Phillips, M., \& Kailasapathy, K. (2013). Effect of encapsulation on the survival of probiotic bacteria in the presence of starter and non-starter lactic acid bacteria in Cheddar cheese over a 6-month ripening period. International Journal of Fermented Foods, 2, 63-76.

Dave, R. I., \& Shah, N. P. (1998). Ingredient supplementation effects on viability of probiotic bacteria in yogurt. Journal of Dairy Science, 81, 2804-2816.

de Ullivarri, M. F., Mendoza, L. M., \& Raya, R. R. (2014). Killer activity of Saccharomyces cerevisiae strains: Partial characterization and strategies to improve the biocontrol efficacy in winemaking. Antonie van Leeuwenhoek, $106,865-878$.

De Vuyst, L., \& Leroy, F. (2007). Bacteriocins from lactic acid bacteria: Production, purification, and food applications. Journal of Molecular Microbiology and Biotechnology, 13, 194-199.

Debeaufort, F., Quezada-Gallo, J. A., \& Voilley, A. (1998). Edible films and coatings: Tomorrow's packagings: A review. Critical Reviews in Food Science and Nutrition, 38, 299-313.

Desmond, C., Ross, R. P., O’Callaghan, E., Fitzgerald, G., \& Stanton, C. (2002). Improved survival of Lactobacillus paracasei NFBC 338 in spray-dried powders containing gum acacia. Journal of Applied Microbiology, 93, 1003-1011.

Di Francesco, A., Ugolini, L., Lazzeri, L., \& Mari, M. (2015). Production of volatile organic compounds by Aureobasidium pullulans as a potential mechanism of action against postharvest fruit pathogens. Biological Control, 81, 8-14.

Doherty, S. B., Auty, M. A., Stanton, C., Ross, R. P., Fitzgerald, G. F., \& Brodkorb, A. (2012). Application of whey protein micro-bead coatings for enhanced strength and probiotic protection during fruit juice storage and gastric incubation. Journal of Microencapsulation, 29, 713-728.

Douglas, L. C., \& Sanders, M. E. (2008). Probiotics and prebiotics in dietetics practice. Journal of the American Dietetic Association, 108, 510-521.

Droby, S., Chalutz, E., Wilson, C. L., \& Wisniewski, M. (1989). Characterization of the biocontrol activity of Debaryomyces hansenii in the control of Penicillium digitatum on grapefruit. Canadian Journal of Microbiology, 35, 794-800.

Droby, S., Vinokur, V., Weiss, B., Cohen, L., Daus, A., Goldschmidt, E. E., \& Porat, R. (2002). Induction of resistance to Penicillium digitatum in grapefruit by the yeast biocontrol agent Candida oleophila. Phytopathology, 92, 393-399.

Druvefors, U., Jonsson, N., Boysen, M. E., \& Schnürer, J. (2002). Efficacy of the biocontrol yeast Pichia anomala during long-term storage of moist feed grain under different oxygen and carbon dioxide regimens. FEMS Yeast Research, 2, 389-394.

Druvefors, U. A., Passoth, V., \& Schnurer, J. (2005). Nutrient effects on biocontrol of Penicillium roqueforti by Pichia anomala J121 during airtight storage of wheat. Applied and Environmental Microbiology, 71, $1865-1869$.

Dunne, C., O’Mahony, L., Murphy, L., Thornton, G., Morrissey, D., O'Halloran, S., .. . Collins, J. K. (2001). In vitro selection criteria for probiotic bacteria of human origin correlation with in vivo findings. American Journal of Clinical Nutrition, 73: 386S-392S.

Edema, M. O., \& Sanni, A. I. (2008). Functional properties of selected starter cultures for sour maize bread. Food Microbiology, 25, 616-625.

El-Ghaouth, A., Wilson, C. L., \& Wisniewski, M. (1998). Ultrastructural and cytochemical aspects of the biological control of Botrytis cinerea by Candida saitoana in apple fruit. Phytopathology, 88, 282-291.

Falguera, V., Quintero, J. P., Jiménez, A., Muñoz, J. A., \& Ibarz, A. (2011). Edible films and coatings: Structures, active functions, and trends in their use. Trends in Food Science \& Technology, 22, 292-303.

Fan, Q., \& Tian, S. (2001). Postharvest biological control of grey mold and blue mold on apple by Cryptococcus albidus (Saito) Skinner. Postharvest Biology and Technology, 21, 341-350.
Fan, Y., Xu, Y., Wang, D., Zhang, L., Sun, J., Sun, L., \& Zhang, B. (2009). Effect of alginate coating combined with yeast antagonist on strawberry (Fragaria $\times$ ananassa) preservation quality. Postharvest Biology and Technology, 53, 84-90.

Farnworth, E. R., Mainville, I., Desjardins, M. P., Gardner, N., Fliss, I., \& Champagne, C. (2007). Growth of probiotic bacteria and bifidobacteria in a soy yogurt formulation. International Journal of Food Microbiology, 116, 174-181.

Gálvez, A., Abriouel, H., López, R. L., \& Omar, N. B. (2007).

Bacteriocin-based strategies for food biopreservation. International Journal of Food Microbiology, 120, 51-70.

Gardiner, G. E., Bouchier, P., O’Sullivan, E., Kelly, J., Collins, J. K., Fitzgerald, G., .. Stanton, C. (2002). A spray-dried culture for probiotic Cheddar cheese manufacture. International Dairy Journal, 12, 749-756.

Gennadios, A. (2002). Protein-based films and coatings. Boca Raton: CRC Press. Gerez, C. L., Carbajo, M. S., Rollan, G., Torres Leal, G., \& Font de Valdez, G. (2010). Inhibition of citrus fungal pathogens by using lactic acid bacteria. Journal of Food Science, 75, M354-M359.

Gialamas, H., Zinoviadou, K. G., Biliaderis, C. G., \& Koutsoumanis, K. P. (2010). Development of a novel bioactive packaging based on the incorporation of Lactobacillus sakei into sodium-caseinate films for controlling Listeria monocytogenes. Food Research International, 43, 24022408 .

Gismondo, M. R., Drago, L., \& Lombardi, A. (1999). Review of probiotics available to modify gastrointestinal flora. International Journal of Antimicrobial Agents, 12, 287-292.

Goerges, S., Aigner, U., Silakowski, B., \& Scherer, S. (2006). Inhibition of Listeria monocytogenes by food-borne yeasts. Applied and Environmental Microbiology, 72, 313-318.

Golubev, W. I. (2006). Antagonistic interactions among yeasts. In: Biodiversity and Ecophysiology of Yeasts (pp. 197-219). Germany: Springer.

Gourama, H., \& Bullerman, L. B. (1997). Anti-aflatoxigenic activity of Lactobacillus casei pseudoplantarum. International Journal of Food Microbiology, 34, 131-143.

Grzegorczyk, M., Żarowska, B., Restuccia, C., \& Cirvilleri, G. (2017).

Postharvest biocontrol ability of killer yeasts against Monilinia fructigena and Monilinia fructicola on stone fruit. Food Microbiology, 61, 93-101.

Gueimonde, M., Delgado, S., Mayo, B., Ruas-Madiedo, P., Margolles, A., \& de los Reyes-Gavilán, C. G. (2004). Viability and diversity of probiotic Lactobacillus and Bifidobacterium populations included in commercial fermented milks. Food Research International, 37, 839-850.

Haïssam, J. M. (2011). Pichia anomala in biocontrol for apples: 20 years of fundamental research and practical applications. Antonie van Leeuwenhoek, 99, 93-105.

Hammond, J. R. M., \& Eckersley, K. W. (1984). Fermentation properties of brewing yeast with killer character. Journal of The Institute of Brewing, 90, 167-177.

Hernández, A., Martín, A., Córdoba, M. G., Benito, M. J., Aranda, E., \& Pérez-Nevado, F. (2008). Determination of killer activity in yeasts isolated from the elaboration of seasoned green table olives. International Journal of Food Microbiology, 121, 178-188.

Hernández, D., Cardell, E., \& Zárate, V. (2005). Antimicrobial activity of lactic acid bacteria isolated from Tenerife cheese: Initial characterization of plantaricin TF711, a bacteriocin-like substance produced by Lactobacillus plantarum TF711. Journal of Applied Microbiology, 99, 77-84.

Hernández-Montiel, L. G., Ochoa, J. L., Troyo-Diéguez, E., \&

Larralde-Corona, C. P. (2010). Biocontrol of postharvest blue mold (Penicillium italicum Wehmer) on Mexican lime by marine and citrus Debaryomyces hansenii isolates. Postharvest Biology and Technology, 56, 181-187.

Hershkovitz, V., Ben-Dayan, C., Raphael, G., Pasmanik-Chor, M., Liu, J. I. A., Belausov, E., ... Droby, S. (2012). Global changes in gene expression of grapefruit peel tissue in response to the yeast biocontrol agent Metschnikowia fructicola. Molecular Plant Pathology, 13, 338-349.

Holzapfel, W. H., Haberer, P., Snel, J., Schillinger, U., \& Veld, J. H. J.Hit. (1998). Overview of gut flora and probiotics. International Journal of Food Microbiology, 41, 85-101.

Holzapfel, W. H., \& Schillinger, U. (2002). Introduction to pre- and probiotics. Food Research International, 35, 109-116.

Homayouni, A., Azizi, A., Ehsani, M. R., Yarmand, M. S., \& Razavi, S. H. (2008). Effect of microencapsulation and resistant starch on the probiotic survival and sensory properties of synbiotic ice cream. Food Chemistry, 111,
$50-55$. 
Huang, R., Li, G. Q., Zhang, J., Yang, L., Che, H. J., Jiang, D. H., \& Huang, H. C. (2011). Control of postharvest botrytis fruit rot of strawberry by volatile organic compounds of Candida intermedia. Phytopathology, 101, 859-869.

Ibrahim, F., Ruvio, S., Granlund, L., Salminen, S., Viitanen, M., \& Ouwehand, A. C. (2010). Probiotics and immunosenescence: Cheese as a carrier. FEMS Immunology and Medical Microbiology, 59, 53-59.

Ippolito, A., El Ghaouth, A., Wilson, C. L., \& Wisniewski, M. (2000). Control of postharvest decay of apple fruit by Aureobasidium pullulans and induction of defense responses. Postharvest Biology and Technology, 19, 265-272.

Iyer, C., \& Kailasapathy, K. (2005). Effect of co-encapsulation of probiotics with prebiotics on increasing the viability of encapsulated bacteria under in vitro acidic and bile salt conditions and in yogurt. Journal of Food Science, 70, $18-23$.

Kabara, J. J., \& Marshall, D. L. (1993). Medium-chain fatty acids and esters. In P. M. Davidson, J. N. Sofos, \& A. L. Branen (Eds.). Antimicrobials in Food (3rd ed., pp. 307-307). United Stades of America: CRC Press.

Kagan, B. L. (1983). Mode of action of yeast killer toxins: Channel formation in lipid bilayer membranes. Nature, 302, 709-711.

Kailasapathy, K. (2006). Survival of free and encapsulated probiotic bacteria and their effect on the sensory properties of yoghurt. LWT- Food Science and Technology, 39, 1221-1227.

Kalogiannis, S., Tjamos, S. E., Stergiou, A., Antoniou, P. P., Ziogas, B. N., \& Tjamos, E. C. (2006). Selection and evaluation of phyllosphere yeasts as biocontrol agents against grey mould of tomato. European Journal of Plant Pathology, 116, 69-76.

Kamzolova, S. V., Shishkanova, N. V., Morgunov, I. G., \& Finogenova, T. V. (2003). Oxygen requirements for growth and citric acid production of Yarrowia lipolytica. FEMS Yeast Research, 3, 217-222.

Kandler, O. (1983). Carbohydrate metabolism in lactic acid bacteria. Antonie van Leeuwenhoek, 49, 209-224.

Kanmani, P., \& Lim, S. T. (2013). Development and characterization of novel probiotic-residing pullulan/starch edible films. Food Chemistry, 141, 1041-1049.

Khan, N. I., Schisler, D. A., Boehm, M. J., Slininger, P. J., \& Bothast, R. J. (2001). Selection and evaluation of microorganisms for biocontrol of Fusarium head blight of wheat incited by Gibberella zeae. Plant Disease, 85, $1253-1258$

Klassen, R., \& Meinhardt, F. (2005). Induction of DNA damage and apoptosis in Saccharomyces cerevisiae by a yeast killer toxin. Cell Microbiology, 7, 393-401.

Kristo, E., Koutsoumanis, K. P., \& Biliaderis, C. G. (2008). Thermal, mechanical and water vapor barrier properties of sodium caseinate films containing antimicrobials and their inhibitory action on Listeria monocytogenes. Food Hydrocolloids, 22, 373-386.

Kumura, H., Tanoue, Y., Tsukahara, M., Tanaka, T., \& Shimazaki, K. (2004). Screening of dairy yeast strains for probiotic applications. Journal of Dairy Scienc, 87, 4050-4056.

Kurtzman, C., Fell, J. W., \& Boekhout, T. (2011). The yeasts: A taxonomic study (5th ed.). London, UK: Elsevier.

Kussendrager, K. D., \& van Hooijdonk, A. C. M. (2000). Lactoperoxidase: Physico-chemical properties, occurrence, mechanism of action, and applications. British Journal of Nutrition, 84, 19-25.

Lassois, L., de Lapeyre de Bellaire, L., \& Jijakli, M. H. (2008). Biological control of crown rot of bananas with Pichia anomala strain K and Candida oleophila strain O. Biology Control, 45, 410-418.

Lavermicocca, P., Valerio, F., Evidente, A., Lazzaroni, S., Corsetti, A., \& Gobbetti, M. (2000). Purification and characterization of novel antifungal compounds from the sourdough Lactobacillus plantarum strain 21B. Applied and Environmental Microbiology, 66, 4084-4090.

Leroy, F., \& De Vuyst, L. (2004). Lactic acid bacteria as functional starter cultures for the food fermentation industry. Trends in Food Science \& Technology, 15, 67-78.

Lima, J. R., Gondim, D. M. F., Oliveira, J. T. A., Oliveira, F. S. A., Gonçalves, L. R. B., \& Viana, F. M. P. (2013). Use of killer yeast in the management of postharvest papaya anthracnose. Postharvest Biology and Technology, 83, 58-64. Lin, D., \& Zhao, Y. (2007). Innovations in the development and application of edible coatings for fresh and minimally processed fruits and vegetables. Comprehensive Reviews in Food Science and Food Safety, 6, 60-75.

Lin, W-H., Lin, C-K., Sheu, S-J., Hwang, C-F, Ye, W-T., Hwang, W-Z., \& Tsen, H-Y. (2009). Antagonistic activity of spent culture supernatants of lactic acid bacteria against Helicobacter Pylori ; growth and infection in human gastric epithelial AGS cells. Journal of Food Science, 74, M225-M30.

Liu, J., Sui, Y., Wisniewski, M., Droby, S., \& Liu, Y. (2013a). Review: Utilization of antagonistic yeasts to manage postharvest fungal diseases of fruit. International Journal of Food Microbiology, 167, 153-160.

Liu, P., Luo, L., \& Long, C-a. (2013b). Characterization of competition for nutrients in the biocontrol of Penicillium italicum by Kloeckera apiculata. Biological Control, 67, 157-162.

Liu, S-Q., \& Tsao, M. (2009a). Biocontrol of dairy moulds by antagonistic dairy yeast Debaryomyces hansenii in yoghurt and cheese at elevated temperatures. Food Control, 20, 852-855.

Liu, S-Q., \& Tsao, M. (2009b). Inhibition of spoilage yeasts in cheese by killer yeast Williopsis saturnus var. saturnus. International Journal of Food Microbiology, 131, 280-282.

Liu, S-Q., \& Tsao, M. (2010). Biocontrol of spoilage yeasts and moulds by Williopsis saturnus var. saturnus in yoghurt. Nutrition \& Food Science, 40, 166-175.

Ljungh, A., \& Wadstrom, T. (2005). Lactic acid bacteria as probiotics. Current Issues in Intestinal Microbiology, 7, 73-90.

Llorente, P., Marquina, D., Santos, A., Peinado, J. M., \& Spencer-Martins, I. (1997). Effect of salt on the killer phenotype of yeasts from olive brines. Applied and Environmental Microbiology, 63, 1165-1167.

Long, C-A., Deng, B-X., \& Deng, X-X. (2007). Commercial testing of Kloeckera apiculata, isolate 34-9, for biological control of postharvest diseases of citrus fruit. Annals of Microbiology, 57, 203-207.

Long, C. A., Wu, Z., \& Deng, B. X. (2005). Biological control of Penicillium italicum of Citrus and Botrytis cinerea of Grape by Strain 34-9 of Kloeckera apiculata. Journal European Food Research and Technology, 221, 197-201.

López de Lacey, A. M., López-Caballero, M. E., Gómez-Estaca, J., Gómez-Guillén, M. C., \& Montero, P. (2012). Functionality of Lactobacillus acidophilus and Bifidobacterium bifidum incorporated to edible coatings and films. Innovative Food Science and Emerging Technologies, 16, 277-282.

López de Lacey, A. M., López-Caballero, M. E., \& Montero, P. (2014). Agar films containing green tea extract and probiotic bacteria for extending fish shelf-life. LWT- Food Science and Technology, 55, 559-564.

Lourens-Hattingh, A., \& Viljoen, B. C. (2001). Growth and survival of a probiotic yeast in dairy products. Food Research International, 34, 791-796.

Lowes, K. F., Shearman, C. A., Payne, J., MacKenzie, D., Archer, D. B., Merry, R. J., \& Gasson, M. J. (2000). Prevention of yeast spoilage in feed and food by the yeast mycocin HMK. Applied and Environmental Microbiology, 66, 1066-1076

Luckow, T., \& Delahunty, C. (2004). Which juice is 'healthier'? A consumer study of probiotic non-dairy juice drinks. Food Quality and Preference, 15, 751-759.

Luo, Y., Zhou, Y., \& Zeng, K. (2013). Effect of Pichia membranaefaciens on ROS metabolism and postharvest disease control in citrus fruit. Crop Protection, 53, 96-102.

Magliani, W., Conti, S., Gerloni, M., Bertolotti, D., \& Polonelli, L. (1997).

Yeast killer systems. Clinical Microbiology Reviews, 10, 369-400.

Magnusson, J. (2003). Antifungal activity of lactic acid bacteria (pp. 38). Uppsala, Sweden: Department of Microbiology, Swedish University of Agricultural Sciences.

Magnusson, J., \& Schnurer, J. (2001). Lactobacillus coryniformis subsp. coryniformis strain $\mathrm{Si} 3$ produces a broad-spectrum proteinaceous antifungal compound. Applied and Environmental Microbiology, 67, 1-5.

Magnusson, J., Ström, K., Roos, S., Sjögren, J., \& Schnürer, J. (2003). Broad and complex antifungal activity among environmental isolates of lactic acid bacteria. FEMS Microbiology Letters, 219, 129-135.

Malmo, C., Storia, A. L., \& Mauriello, G. (2013). Microencapsulation of Lactobacillus reuteri DSM 17938 cells coated in alginate beads with chitosan by spray drying to use as a probiotic cell in a chocolate soufflé. Food Bioprocess Technology, 6, 795-805.

Marín, A., Atarés, L., Cháfer, M., \& Chiralt, A. (2017). Properties of biopolymer dispersions and films used as carriers of the biocontrol agent Candida sake CPA-1. LWT-Food Science Technology, 79, 60-69.

Marín, A., Cháfer, M., Atarés, L., Chiralt, A., Torres, R., Usall, J., \& Teixido, N. (2016). Effect of different coating-forming agents on the efficacy of the biocontrol agent Candida sake CPA-1 for control of Botrytis cinerea on grapes. Biological Control, 96, 108-119.

Marquina, D., Barroso, J., Santos, A., \& Peinado, J. M. (2001). Production and characteristics of Debaryomyces hansenii killer toxin. Microbiological Research, 156, 387-391. 
Marquina, D., Santos, A., \& Peinado, J. (2002). Biology of killer yeasts. International Microbiology, 5, 65-71.

Masih, E. I., \& Paul, B. (2002). Secretion of $\beta-1,3$-glucanases by the yeast Pichia membranifaciens and Its possible role in the biocontrol of Botrytis cinerea causing grey mold disease of the grapevine. Current Microbiology, 44, 391-395.

Mattila-Sandholm, T., Myllarinen, P., Crittenden, R., Mogensen, G., Fonden, R., \& Saarela, M. (2002). Technological challenges for future probiotic foods. International Dairy Journal, 12, 173-182.

McGuire, R. G., \& Baldwin, E. A. (1994). Compositions of cellulose coatings affect populations of yeasts in the liquid formulation and on coated grapefruits. Proceedings of the Florida State Horticultural Society, 107, 293293.

McGuire, R. G., \& Dimitroglou, D. A. (1999). Evaluation of shellac and sucrose ester fruit coating formulations that support biological control of post-harvest grapefruit decay. Biocontrol Science and Technology, 9, $53-65$.

McGuire, R. G., \& Hagenmaier, R. D. (1996). Shellac coatings for grapefruits that favor biological control of Penicillium digitatum by Candida oleophila. Biol Control, 7, 100-106.

Messi, P., Bondi, M., Sabia, C., Battini, R., \& Manicardi, G. (2001). Detection and preliminary characterization of a bacteriocin (plantaricin 35d) produced by a Lactobacillus plantarum strain. International Journal of Food Microbiology, 64, 193-198.

Mokiou, S., \& Magan, N. (2008). Physiological manipulation and formulation of the biocontrol yeast Pichia anomala for control of Penicillium verrucosum and ochratoxin A contamination of moist grain. Biocontrol Science and Technology, 18, 1063-1073.

Morales, H., Sanchis, V., Usall, J., Ramos, A. J., \& Marín, S. (2008). Effect of biocontrol agents Candida sake and Pantoea agglomerans on Penicillium expansum growth and patulin accumulation in apples. International Journal of Food Microbiology, 122, 61-67.

Muccilli, S., Wemhoff, S., Restuccia, C., \& Meinhardt, F. (2013). Exoglucanase-encoding genes from three Wickerhamomyces anomalus killer strains isolated from olive brine. Yeast, 30, 33-43.

Muthukumarasamy, P., \& Holley, R. A. (2006). Microbiological and sensory quality of dry fermented sausages containing alginate-microencapsulated Lactobacillus reuteri. International Journal of Food Microbiology, 111, 164-169.

Muthukumarasamy, P., \& Holley, R. A. (2007). Survival of Escherichia coli O157 H7 in dry fermented sausages containing micro-encapsulated probiotic lactic acid bacteria. Food Microbiology, 24, 82-88.

Nes, I. F., \& Holo, H. (2000). Class II antimicrobial peptides from lactic acid bacteria. Journal of Peptide Science, 55, 50-61.

Niku-Paavola, M. L., Laitila, A., Mattila-Sandholm, T., \& Haikara, A. (1999). New types of antimicrobial compounds produced by Lactobacillus plantarum. J Applied Microbiology, 86, 29-35.

Nualkaekul, S., Cook, M. T., Khutoryanskiy, V. V., \& Charalampopoulos, D. (2013). Influence of encapsulation and coating materials on the survival of Lactobacillus plantarum and Bifidobacterium longum in fruit juices. Food Research International, 53, 304-311.

Nunes, C., Usall, J., Teixidó, N., Fons, E., \& Viñas, I. (2002). Post-harvest biological control by Pantoea agglomerans (CPA-2) on Golden Delicious apples. Journal of Applied Microbiology, 92, 247-255.

Nunes, C. A. (2012). Biological control of postharvest diseases of fruit. European Journal of Plant Pathology, 133, 181-196.

Ohland, C. L., \& MacNaughton, W. K. (2010). Probiotic bacteria and intestinal epithelial barrier function. American Journal of Physiology-Gastrointestinal and Liver Physiology, 298, G807-G19.

Parafati, L., Vitale, A., Restuccia, C., \& Cirvilleri, G. (2015). Biocontrol ability and action mechanism of food-isolated yeast strains against Botrytis cinerea causing post-harvest bunch rot of table grape. Food Microbiology, 47, 85-92.

Parafati, L., Vitale, A., Restuccia, C., \& Cirvilleri, G. (2016). The effect of locust bean gum (LBG)-based edible coatings carrying biocontrol yeasts against Penicillium digitatum and Penicillium italicum causal agents of postharvest decay of mandarin fruit. Food Microbiology, 58, 87-94.

Parvez, S., Malik, K. A., Kang, S. A., \& Kim, H-Y. (2006). Probiotics and their fermented food products are beneficial for health. Journal of Applied Microbiology, 100, 1171-1185.

Pawlowska, A. M., Zannini, E., Coffey, A., \& Arendt, E. K. (2012). "Green preservaives": Combating fungi in the food and feed industry by applying antifungal lactic acid bacteria. In J. Henry (Ed.). Advances in food and nutrition research (pp. 217-238). USA: Elsevier.
Peláez, A. M. L., Cataño, C. A. S., Yepes, E. A. Q., Villarroel, R. R. G., De Antoni, G. L., \& Giannuzzi, L. (2012). Inhibitory activity of lactic and acetic acid on Aspergillus flavus growth for food preservation. Food Control, 24, 177-183.

Pereira, J. O., Soares, J., Sousa, S., Madureira, A. R., Gomes, A., \& Pintado, M. (2016). Edible films as carrier for lactic acid bacteria. LWT- Journal of Food Science and Technology, 73, 543-550.

Petersson, S., Hansen, M. W., Axberg, K., Hult, K., \& Schnürer, J. (1998). Ochratoxin A accumulation in cultures of Penicillium verrucosum with the antagonistic yeast Pichia anomala and Saccharomyces cerevisiae. Mycological Research, 102, 1003-1008.

Petersson, S., \& Schnürer, J. (1995). Biocontrol of mold growth in high-moisture wheat stored under airtight conditions by Pichia anomala, Pichia guilliermondii, and Saccharomyces cerevisiae. Applied and Environmental Microbiology, 61, 1027-1032.

Platania, C., Restuccia, C., Muccilli, S., \& Cirvilleri, G. (2012). Efficacy of killer yeasts in the biological control of Penicillium digitatum on Tarocco orange fruits (Citrus sinensis). Food Microbiology, 30, 219-225.

Ponts, N., Pinson-Gadais, L., Verdal-Bonnin, M-N., Barreau, C., \& Richard-Forget, F. (2006). Accumulation of deoxynivalenol and its 15 -acetylated form is significantly modulated by oxidative stress in liquid cultures of Fusarium graminearum. FEMS Microbiology Letters, 258, 102-107.

Possemiers, S., Marzorati, M., Verstraete, W., \& Wiele, T. V.d (2010). Bacteria and chocolate: A successful combination for probiotic delivery. International Journal of Food Microbiology, 147, 97-103.

Potjewijd, R., Nisperos, M. O., Burns, J. K., Parish, M., \& Baldwin, E. A. (1995). Cellulose-based coatings as carriers for Candida guillermondii and Debaryomyces sp. in reducing decay of oranges. Hort Science, 30, 1417-1421.

Price, R. J., \& Lee, J. S. (1970). Inhibition of Pseudomonas species by hydrogen peroxide producing Lactobacilli. Journal of Milk Technology, 33 , 13-18.

Psani, M., \& Kotzekidou. (2006). Technological characteristics of yeast strains and their potential as starter adjuncts in Greek-style black olive fermentation. World Journal of Microbiology \& Biotechnology, 22, 1329-1336.

Qin, G. Z., Tian, S. P., Xu, Y., Chan, Z. L., \& Li, B. Q. (2006).

Combination of antagonistic yeasts with 2 food additives for control of brown rot caused by Monilinia fructicola on sweet cherry fruit. Journal of Applied Microbiology, 100, 508-515.

Qing, F., \& Shiping, T. (2000). Postharvest biological control of Rhizopus Rot of Nectarine fruits by Pichia membranefaciens. Plant Diseases, 84, 1212-1216.

Quirós-Sauceda, A. E., Ayala-Zavala, J. F., Olivas, G., \& González-Aguilar, G. A. (2014). Edible coatings as encapsulating matrices for bioactive compounds: A review. Journal of Food Science and Technology, 51, 1674-1685.

Ramos, P. E., Cerqueira, M. A., Teixeira, J. A., \& Vicente, A. A. (2017). Physiological protection of probiotic microcapsules by coatings. Critical Reviews in Food Science and Nutrition, 1-14.

Reyes, M. E. Q., Rohrbach, K. G., \& Paull, R. E. (2004). Microbial antagonists control postharvest black rot of pineapple fruit. Postharvest Biology and Technology, 33, 193-203.

Rivera-Espinoza, Y., \& Gallardo-Navarro, Y. (2010). Non-dairy probiotic products. Food Microbiology, 27, 1-11.

Rodgers, S. (2001). Preserving non-fermented refrigerated foods with microbial cultures—a review. Trends in Food Science \& Technology, 12, 276-284.

Rodgers, S. (2008). Novel applications of live bacteria in food services: Probiotics and protective cultures. Trends in Food Science \& Technology, 19, 188-197.

Rojas-Graü, M. A., Soliva-Fortuny, R., \& Martín-Belloso, O. (2009). Edible coatings to incorporate active ingredients to fresh-cut fruits: A review. Trends in Food Science \& Technology, 20, 438-447.

Romano, N., Tavera-Quiroz, M. J., Bertola, N., Mobili, P., Pinotti, A., \& Gómez-Zavaglia, A. (2014). Edible methylcellulose-based films containing fructo-oligosaccharides as vehicles for lactic acid bacteria. Food Research International, 64, 560-566.

Saarela, M., Mogensen, G., Fondén, R., Matto, J., \& Mattila-Sandholm, T. (2000). Probiotic bacteria safety, functional, and technological properties. Journal of Biotechnology, 84, 197-215.

Saligkarias, I. D., Gravanis, F. T., \& Epton, H. A. S. (2002). Biological control of Botrytis cinerea on tomato plants by the use of epiphytic yeasts Candida guilliermondii strains 101 and US 7 and Candida oleophila strain I-182: I. In vivo studies. Biological Control, 25, 143-150. 
Sánchez-González, L., Quintero Saavedra, J. I., \& Chiralt, A. (2013). Physical properties and antilisterial activity of bioactive edible films containing Lactobacillus plantarum. Food Hydrocoll, 33, 92-98.

Sánchez-González, L., Quintero Saavedra, J. I., \& Chiralt, A. (2014). Antilisterial and physical properties of biopolymer films containing lactic acid bacteria. Food Control, 35, 200-206.

Sanders, M. E. (2008). Probiotics: Definition, sources, selection, and uses. Clinical Infectious Diseases, 46, 58-61.

Santos, A., \& Marquina, D. (2004). Killer toxin of Pichia membranifaciens and its possible use as a biocontrol agent against grey mould disease of grapevine. Microbiology, 150, 2527-2534.

Santos, A., Navascués, E., Bravo, E., \& Marquina, D. (2011). Ustilago maydis killer toxin as a new tool for the biocontrol of the wine spoilage yeast Brettanomyces bruxellensis. International Journal of Food Microbiology, 145, 147-154.

Santos, A., San Mauro, M., Abrusci, C., \& Marquina, D. (2007). Cwp2p, the plasma membrane receptor for Pichia membranifaciens killer toxin. Molecular Microbiology, 64, 831-843

Santos, A., Sánchez, A., \& Marquina, D. (2004). Yeasts as biological agents to control Botrytis cinerea. Microbiological Research, 159, 331-338.

Saravanakumar, D., Ciavorella, A., Spadaro, D., Garibaldi, A., \& Gullino, M. L. (2008). Metschnikowia pulcherrima strain MACH1 outcompetes Botrytis cinerea, Alternaria alternata and Penicillium expansum in apples through iron depletion. Postharvest Biology and Technology, 49, 121-128.

Sazawal, S., Hiremath, G., Dhingra, U., Malik, P., Deb, S., \& Black, R. E. (2006). Efficacy of probiotics in prevention of acute diarrhoea: A meta-analysis of masked, randomised, placebo-controlled trials. Lancet Infectious Diseases, 6, 374-382.

Schisler, D. A., Slininger, P. J., \& Bothast, R. J. (1997). Effects of antagonist cell concentration and two-strain mixtures on biological control of Fusarium dry rot of potatoes. Phytopathology, 87, 177-183.

Schmitt, M. J., \& Breinig, F. (2002). The viral killer system in yeast: From molecular biology to application. FEMS Microbiological Reviews, 26, 257-276.

Schnürer, J., \& Magnusson, J. (2005). Antifungal lactic acid bacteria as biopreservatives. Trends in Food Science \& Technology, 16, 70-78.

Seifu, E., Buys, E. M., \& Donkin, E. F. (2005). Significance of the lactoperoxidase system in the dairy industry and its potential applications: A review. Trends in Food Science \& Technology, 16, 137-154.

Shah, N. P., \& Ravula, R. R. (2000). Microencapsulation of probiotic bacteria and their survival in frozen fermented dairy desserts. Australian Journal of Dairy Technology, 55, 139.

Sharma, N., Verma, U., \& Awasthi, P. (2006). A combination of the yeast Candida utilis and chitosan controls fruit rot in tomato caused by Alternaria alternata (Fr.) Keissler and Geotrichum candidum Link ex Pers. Journal of Horticultural Science and Biotechnology, 81, 1043-1051.

Sharma, R. R., Singh, D., \& Singh, R. (2009). Biological control of postharvest diseases of fruits and vegetables by microbial antagonists: A review. Biological Control, 50, 205-221.

Sheehan, V. M., Ross, P., \& Fitzgerald, G. F. (2007). Assessing the acid tolerance and the technological robustness of probiotic cultures for fortification in fruit juices. Innovative Food Science and Emerging Technologies, 8, 279-284.

Silva, T., Reto, M., Sol, M., Peito, A., Peres, C. M., Peres, C., \& Malcata, F X. (2011). Characterization of yeasts from Portuguese brined olives, with a focus on their potentially probiotic behavior. LWT-Journal of Food Science and Technology, 44, 1349-1354.

Sipiczki, M. (2006). Metschnikowia strains isolated from botrytized grapes antagonize fungal and bacterial growth by iron depletion. Applied and Environmental Microbiology, 72, 6716-6724.

Sjogren, J., Magnusson, J., Broberg, A., Schnurer, J., \& Kenne, L. (2003). Antifungal 3-hydroxy fatty acids from Lactobacillus plantarum MiLAB 14. Applied and Environmental Microbiology, 69, 7554-7557.

Soukoulis, C., Behboudi-Jobbehdar, S., Macnaughtan, W., Parmenter, C., \& Fisk, I. D. (2017). Stability of Lactobacillus rhamnosus GG incorporated in edible films: Impact of anionic biopolymers and whey protein concentrate. Food Hydrocolloids, 70, 345-355.

Soukoulis, C., Behboudi-Jobbehdar, S., Yonekura, L., Parmenter, C., \& Fisk, I. D. (2014a). Stability of Lactobacillus rhamnosus GG in prebiotic edible films. Food Chemistry, 159, 302-308.

Soukoulis, C., Singh, P., Macnaughtan, W., Parmenter, C., \& Fisk, I. D.

(2016). Compositional and physicochemical factors governing the viability of Lactobacillus rhamnosus GG embedded in starch-protein based edible films. Food Hydrocolloids, 52, 876-887.

Soukoulis, C., Yonekura, L., Gan, H-H., Behboudi-Jobbehdar, S., Parmenter, C., \& Fisk, I. (2014b). Probiotic edible films as a new strategy for developing functional bakery products The case of pan bread. Food Hydrocolloids, 39, 231-242.

Spadaro, D., \& Droby, S. (2016). Development of biocontrol products for postharvest diseases of fruit: The importance of elucidating the mechanisms of action of yeast antagonists. Trends in Food Science \& Technology, 47, $39-49$.

Spadaro, D., Garibaldi, A., \& Gullino, M. L. (2004). Control of Penicillium expansum and Botrytis cinerea on apple combining a biocontrol agent with hot water dipping and acibenzolar-S-methyl, baking soda, or ethanol application. Postharvest Biology and Technology, 33, 141-151.

Spencer, J. F. T., \& Spencer, D. M. (2013). Yeasts in natural and artificial habitats. Springer Science \& Business Media.

Spinler, J. K., Taweechotipatr, M., Rognerud, C. L., Ou, C. N., Tumwasorn, S., \& Versalovic, J. (2008). Human-derived probiotic Lactobacillus reuteri demonstrate antimicrobial activities targeting diverse enteric bacterial pathogens. Anaerobe, 14, 166-171.

Ström, K., Sjögren, J., Broberg, A., \& Schnürer, J. (2002). Lactobacillus plantarum MiLAB 393 produces the antifungal cyclic dipeptides cyclo (1-Phe-1-Pro) and cyclo(1-Phe-trans-4-OH-1-Pro) and 3-phenyllactic acid. Applied and Environmental Microbiology, 68, 4322-4327.

Sultana, K., Godward, G., Reynolds, N., Arumugaswamy, R., Peiris, P., \& Kailasapathy, K. (2000). Encapsulation of probiotic bacteria with alginate-starch and evaluation of survival in simulated gastrointestinal conditions and in yoghurt. International Journal of Food Microbiology, 62, $47-55$.

Surawicz, C. M., Elmer, G. W., Speelman, P., McFarland, L. V., Chinn, J., \& Van Belle, G. (1989). Prevention of antibiotic-associated diarrhea by Saccharomyces boulardii: A prospective study. Gastroenterology, 96, 981-988.

Suzuki, C., Ando, Y., \& Machida, S. (2001). Interaction of SMKT, a killer toxin produced by Pichia farinosa, with the yeast cell membranes. Yeast, 18 , 1471-1478

Tapia, M. S., Rojas-Grau, M. A., Rodríguez, F. J., Ramírez, J., Carmona, A. \& Martin-Belloso, O. (2007). Alginate- and gellan-based edible films for probiotic coatings on fresh-cut fruits. Journal of Food Science, 72, 190-196.

Taqarort, N., Echairi, A., Chaussod, R., Nouaim, R., Boubaker, H., Benaoumar, A. A., \& Boudyach, E. (2008). Screening and identification of epiphytic yeasts with potential for biological control of green mold of citrus fruits. World Journal of Microbiology \& Biotechnology, 24, 3031-3038.

Tavera-Quiroz, M. J., Romano, N., Mobili, P., Pinotti, A., Gómez-Zavaglia, A., \& Bertola, N. (2015). Green apple baked snacks functionalized with edible coatings of methylcellulose containing Lactobacillus plantarum. Journal of Functional Foods, 16, 164-173.

Teixidó, N., Usall, J., Palou, L., Asensio, A., Nunes, C., \& Viñas, I. (2001). Improving control of green and blue molds of oranges by combining Pantoea Agglomerans (CPA-2) and sodium bicarbonate. European Journal of Plant Pathology, 107, 685-694.

Tharanathan, R. N. (2003). Biodegradable films and composite coatings: Past, present, and future. Trends in Food Science \& Technology, 14, 71-78.

Tian, S., Fan, Q., Xu, Y., \& Liu, H. (2002). Biocontrol efficacy of antagonist yeasts to gray mold and blue mold on apples and pears in controlled atmospheres. Plant Diseases, 86, 848-853.

Torres, R., Nunes, C., García, J. M., Abadias, M., Viñas, I., Manso, T., .. Usall, J. (2007). Application of Pantoea agglomerans CPA-2 in combination with heated sodium bicarbonate solutions to control the major postharvest diseases affecting citrus fruit at several mediterranean locations. European Journal of Plant Pathology, 118, 73-83.

Torres, R., Teixidó, N., Usall, J., Abadias, M., Mir, N., Larrigaudiere, C., \& Viñas, I. (2011). Anti-oxidant activity of oranges after infection with the pathogen Penicillium digitatum or treatment with the biocontrol agent Pantoea agglomerans CPA-2. Biology Control, 57, 103-109.

Tripathi, M. K., \& Giri, S. K. (2014). Probiotic functional foods: Survival of probiotics during processing and storage. Journal of Functional Foods, 9, 225-241

Tronsmo, A., \& Dennis, C. (1977). The use of Trichoderma species to control strawberry fruit rots. Netherlands Journal of Plant Pathology, $83,449$.

Valerio, F., Lavermicocca, P., Pascale, M., \& Visconti, A. (2004). Production of phenyllactic acid by lactic acid bacteria: An approach to the selection of 
strains contributing to food quality and preservation. FEMS Microbiology Letters, 233, 289-295.

van der Aa Kühle, A., Skovgaard, K., \& Jespersen, L. (2005). In vitro screening of probiotic properties of Saccharomyces cerevisiae var. boulardii and food-borne Saccharomyces cerevisiae strains. International Journal of Food Microbiology, 101, 29-39.

Viñas, I., Usall, J., Teixidó, N., \& Sanchis, V. (1998). Biological control of major postharvest pathogens on apple with Candida sake. International Journal of Food Microbiology, 40, 9-16.

Vivekananthan, R., Ravi, M., Ramanathan, A., \& Samiyappan, R. (2004). Lytic enzymes induced by Pseudomonas fluorescens and other biocontrol organisms mediate defence against the anthracnose pathogen in mango. World Journal of Microbiology \& Biotechnology, 20, 235-244.

Voulgari, K., Hatzikamari, M., Delepoglou, A., Georgakopoulos, P., Litopoulou-Tzanetaki, E., \& Tzanetakis, N. (2010). Antifungal activity of non-starter lactic acid bacteria isolates from dairy products. Food Control, 21, 136-142.

Walker, G. M. (2011). Pichia anomala: Cell physiology and biotechnology relative to other yeasts. Antonie Van Leeuwenhoek, 99, 25-34.

Wang, Y-C., Yu, R-C., \& Chou, C-C. (2006). Antioxidative activities of soy milk fermented with lactic acid bacteria and bifidobacteria. Food Microbiology, 23, 128-135.

Wilson, C. L., \& Chalutz, E. (1989). Postharvest biological control of Penicillium rots of citrus with antagonistic yeasts and bacteria. Scientia Horticulturae, 40, 105-112.

Wisniewski, M., Droby, S., Chalutz, E., \& Eilam, Y. (1995). Effects of $\mathrm{Ca} 2+$ and $\mathrm{Mg} 2+$ on Botrytis cinerea and Penicillium expansum in vitro and on the biocontrol activity of Candida oleophila. Plant Pathology, 44, 10161024.

Woolford, M. K. (1975). Microbiological screening of the straight chain fatty acids (c1-c12) as potential silage additives. Journal of the Science of Food and Agriculture, 26, 219-228.

Xu, X., Qin, G., \& Tian, S. (2008). Effect of microbial biocontrol agents on alleviating oxidative damage of peach fruit subjected to fungal pathogen. International Journal of Food Microbiology, 126, 153-158.
Yao, H. J., \& Tian, S. P. (2005). Effects of a biocontrol agent and methyl jasmonate on postharvest diseases of peach fruit and the possible mechanisms involved. Journal of Applied Microbiology, 98, 941-950.

Yinga, D., Schwander, S., Weerakkody, R., Sanguansri, L., Gantenbein-Demarchi, C., \& Augustin, M. A. (2013). Microencapsulated Lactobacillus rhamnosus GG in whey protein and resistant starch matrices: Probiotic survival in fruit juice. Journal of Functional Foods, 5, 98-105.

Yinzhe, R., \& Shaoying, Z. (2013). Effect of carboxymethyl cellulose and alginate coating combined with brewer yeast on postharvest grape preservation. ISRN Agronomy 2013.

Yoon, K. Y., Woodams, E. E., \& Hang, Y. D. (2004). Probiotication of tomato juice by lactic acid bacteria. Journal of Clinical Microbiology, 42, 315-318.

Yoshiuchi, K., Watanabe, M., \& Nishimura, A. (2000). Breeding of a non-urea producing sake yeast with killer character using a kar1-1 mutant as a killer donor. Journal of Industrial Microbiology and Biotechnology, 24, 203-209

Young, J. (1998). European market developments in prebiotic-and probiotic-containing foodstuffs. British Journal of Nutrition, 80, S231-S233.

Zhang, D., Spadaro, D., Garibaldi, A., \& Gullino, M. L. (2011). Potential biocontrol activity of a strain of Pichia guilliermondii against grey mold of apples and its possible modes of action. Biological Control, 57, 193-201.

Zhang, H., Wang, L., Dong, Y., Jiang, S., Cao, J., \& Meng, R. (2007a). Postharvest biological control of gray mold decay of strawberry with Rhodotorula glutinis. Biological Control, 40, 287-292.

Zhang, H., Wang, L., Ma, L., Dong, Y., Jiang, S., Xu, B., \& Zheng, X. (2009). Biocontrol of major postharvest pathogens on apple using Rhodotorula glutinis and its effects on postharvest quality parameters. Biological Control, 48, 79-83.

Zhang, H., Zheng, X., \& Yu, T. (2007b). Biological control of postharvest diseases of peach with Cryptococcus laurentii. Food Control, 18, 287-291.

Zhou, Y., Ming, J., Deng, L., \& Zeng, K. (2014). Effect of Pichia membranaefaciens in combination with salicylic acid on postharvest blue and green mold decay in citrus fruits. Biological Control, 74, 21-29. 